\title{
EFEITO DA MANIPULAÇÃO DO COMPLEXO TUBO NEURAL/NOTOCORDA NO PADRÃO DE EXPRESSÃO DO FATOR MIOGÊNICO MYOD E NA PROLIFERAÇÃO CELULAR EM EMBRIÕES DE GALINHA
}

\section{HELENA JAVIEL ALVES}

Médica Veterinária

Orientador: Prof. Dr. LUIZ LEHMANN COUTINHO

Dissertação apresentada à Escola Superior de Agricultura "Luiz de Queiroz", Universidade de São Paulo, para obtenção do título de Mestre em Agronomia, Área de Concentração:

Ciência Animal e Pastagens.

PIRACICABA

Estado de São Paulo - Brasil

Maio - 2000 
Dados Internacionais de Catalogação na Publicação (CIP) DIVISÃO DE BIBLIOTECA E DOCUMENTAÇÃO - Campus "Luiz de Oueiroz"/USP

\footnotetext{
Alves, Helena Javiel

Efeito da manipulação do complexo tubo neural/notocorda no padrão de expressão do fator miogênico Myod e na proliferação celular em embriōes de galinha / Helena Javiel Alves. - - Piracicaba, 2000.

51 p. : ii.

Dissertação (mestrado) - Escola Superior de Agricultura Luiz de Queiroz, 2000. Bibliografia.

1. Ave doméstica 2. Embriologia animal 3. Expressão gênica 4. Hibridação 5.

Melhoramento genético animal I. Título
}

CDD 636.50824 


\section{AGRADECIMENTOS}

\section{À Deus.}

Ao Prof. Dr. Luiz Lehmann Coutinho, agradeço pela oportunidade, orientação e pelos valiosos ensinamentos.

Ao Conselho Nacional de Desenvolvimento Científico e Tecnológico (CNPq) pela bolsa de estudos concedida.

Aos professores do Departamento de Produção Animal pelos ensinamentos adquiridos.

Às secretárias do Departamento de Produção Animal, Cláudia C. de Camargo e Vera Lúcia Graciano pelo bom atendimento e atenção recebidos.

À funcionária Marli Kazue Misaki Soares, Departamento de Ciências Biológicas, que sempre me atendeu com boa vontade e atenção.

Ao colega Mário Lúcio Lopes, pela valiosa ajuda e atenção recebidas.

Às amigas Jane Eire Gabriel e Lúcia Elvira Álvares, pela amizade, apoio e especialmente pela ajuda e ensinamentos recebidos.

Aos meus pais e irmãos, pelo incentivo, carinho e apoio sempre recebidos.

Ao Junior, meu namorado, por sempre me apoiar e me dar força em todos os momentos.

À todo o pessoal do Laboratório de Biotecnologia Animal pelo convívio e amizade.

À todos aqueles que de alguma maneira contribuiram para a realização deste trabalho. 


\section{SUMÁRIO}

Página

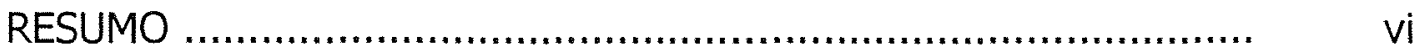

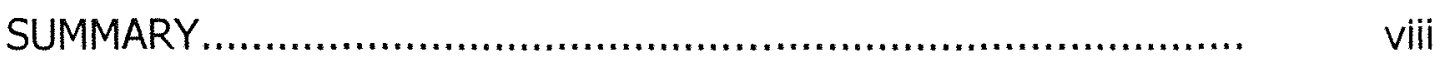

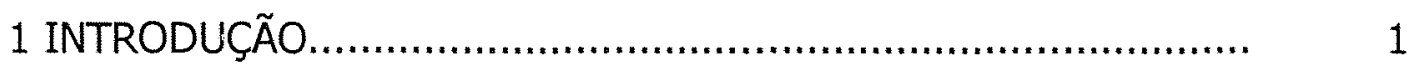

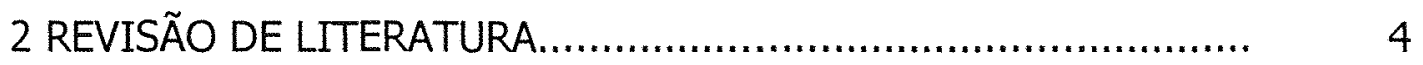

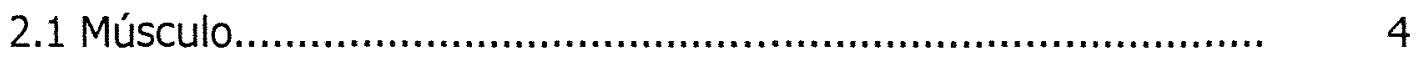

2.2 Formação do músculo esquelético...........................................

2.3 Influência das estruturas axiais na miogênese............................ 8

2.4 Proliferação celular e MyoD ................................................... 10

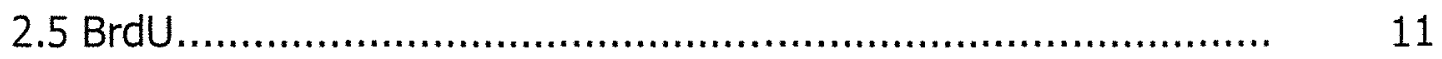

3 MATERIAL E MÉTODOS .................................................. 12

3.1 Incubação dos ovos e coleta dos embriões............................... 12

3.2 Microcirurgia para afastamento e reaproximação dos somitos do tubo neural/notocorda............................................................ 12

3.3 Obtenção e preparação da sonda........................................... 13

3.4 Hibridação "in situ" ............................................................... 14

3.5 Marcação das células em proliferação com BrdU......................... 15

3.6 Preparação de cortes histológicos............................................. 16

3.7 Imunodeteç̧ão do BrdU nos cortes................................... 16

3.8 Extração de RNA total.......................................................... 17

3.9 Síntese de CDNA e RT-PCR Quantitativo................................. 18

4 RESULTADOS E DISCUSSÃO.............................................. 20

4.1 Expressão do fator miogênico MyoD em embriões de galinha......... 20 
4.2 Influência do tubo neural e notocorda na expressão de MyoD.......... 22

4.3 Reaproximação dos somitos e complexo tubo neural/notocorda....... 24

4.4 Análise da expressão de MyoD com o uso da RT-PCR .................... 25

4.5 Proliferação celular em embriões submetidos à microcirurgia........... 28

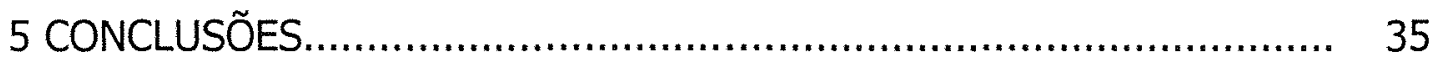

REFERÊNCIAS BIBLIOGRÁFICAS.......................................... 36

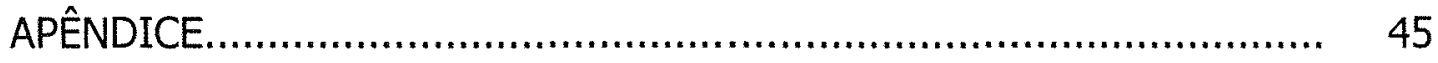




\section{EFEITO DA MANIPULAÇÃO DO COMPLEXO TUBO \\ NEURAL/NOTOCORDA NO PADRÃO DE EXPRESSÃO DO FATOR MIOGÊNICO MYOD E NA PROLIFERAÇÃO CELULAR EM EMBRIÕES DE GALINHA}

Autora: HELENA JAVIEL ALVES

Orientador: Prof. Dr. LUIZ LEHMANN COUTINHO

\section{RESUMO}

Avanços importantes na compreensão do processo de formação da musculatura esquelética foram realizados nos últimos anos. Alguns dos fatores miogênicos responsáveis pela determinação e diferenciação de células musculares foram clonados e progressos significativos foram obtidos quanto ao controle da expressão dos mesmos. Em estudos conduzidos com aves selecionadas para crescimento acelerado, foi determinado um atraso na ativação dos fatores miogênicos durante o desenvolvimento embrionário. Esses estudos levaram à formulação da hipótese de que um atraso na ativação dos fatores miogênicos pode permitir que as células dos somitos continuem a proliferar por mais tempo, permitindo assim um aumento no número de células precursoras de células musculares. Embriões de galinha no estádio 12 de desenvolvimento foram submetidos à microcirurgia para o afastamento e reaproximação do complexo tubo neural/notocorda dos três últimos somitos e parte da placa segmentar $A$ análise da expressão do fator miogênico MyoD foi realizada com a utilização das técnicas de hibridação "in situ" e RT-PCR (do inglês, "reverse transcription-polymerase chain reaction"). Para a análise da 
proliferação celular, a incorporação de BrdU (análogo da timidina) foi feita nos embriões e detectada em cortes histológicos. A expressão do fator miogênico MyoD não foi detectada nos somitos afastados do tubo neural/notocorda. Porém, a reaproximação das estruturas permitiu que o MyoD voltasse a ser expresso. Com relação à proliferação celular, foi observado menor número de células em proliferação na região de formação do somito afastada do tubo neural. Esses resultados confirmam a influência das estruturas axiais na ativação do fator miogênico MyoD em embriões de galinha. 


\title{
EFFECT OF MANIPULATING THE NEURAL TUBE/NOTOCHORD COMPLEX ON STANDARD MYOGENIC FACTOR MYOD EXPRESSION AND CELLULAR PROLIFERATION IN CHICKEN EMBRYOS
}

\author{
Author: Helena Javiel Alves \\ Adviser: Prof. Dr. Luiz Lehmann Coutinho
}

\section{SUMMARY}

Important advances have been made within the last few years in understanding the process of skeletal muscle formation. Some myogenic factors responsible for the determination and differentiation of muscle cells were cloned. Significant progress was made in controlling cellular expression. Studies conducted on poultry selected for accelerated growth detected a delay in activation of myogenic factors during embryo development. These studies led to the hypothesis that a delay in myogenic activation may allow somite cells to continue proliferating for more time and thus increase the number of cells preceding muscle cells. Chicken embryos in developmental stage 12 were submitted to microsurgery to separate and re-approach the neural tube /notochord complex of the last three somites and part of the segmental plate. Expression of myogenic factor MyoD was analyzed with in situ hybridization techniques using an antisense RNA probe and reverse transcription-polymerase chain reaction. To analyze cellular proliferation, BrdU (thymidine analogue) was incorporated into the embryos and detected by histological cuts. Expression of myogenic factor MyoD was not detected in somites separated from the neural tube/ notochord. However, approximation of the structures allowed MyoD to be newly expressed. As for cellular proliferation, a smaller number of proliferating 
cells were observed in the formation region of somites separated from the neural tube. These results confirm the influence of axial structures on activation of myogenic factor MyoD in chicken embryos. 


\section{INTRODUÇÃO}

Por várias décadas, os programas de melhoramento animal têm desenvolvido estratégias a fim de promover melhoria no desempenho e aumento na produção de diversas espécies domésticas. Desta forma, animais vêm sendo selecionados por muitas gerações, resultando em aumento da freqüência de genes associados a características fenotípicas desejáveis. Através da seleção na produção de frangos de corte, tem sido obtidos aumentos ao redor de1 a $2 \%$ de no ganho de peso ao ano. Apesar do sucesso obtido com este procedimento, novas alternativas vêm sendo estabelecidas visando a obtenção de frangos de corte com maior acúmulo de massa muscular. Uma destas alternativas é a manipulação de genes através de técnicas de biologia molecular que tem se mostrado uma valiosa ferramenta nesta área de pesquisa. Para isto, é necessário um conhecimento profundo dos mecanismos moleculares básicos envolvidos no desenvolvimento do tecido muscular esquelético nas aves.

O músculo esquelético tem sido objeto de intensa investigação celular, o que tem levado a um entendimento detalhado dos eventos envolvidos no processo de formação deste tecido (Weintraub et al.,1991). A musculatura esquelética deriva de somitos individuais, que inicialmente formam a musculatura axial e a do tronco e, posteriormente, a dos membros (Wachtler \& Christ, 1992).

Com o advento das técnicas de biologia molecular, a identificação e o isolamento de inúmeros genes responsáveis por promover a ativação dos eventos envolvidos na determinação e diferenciação das células musculares 
esqueléticas têm possibilitado uma análise do controle que estruturas axiais desempenham durante a miogênese em aves.

Vários genes responsáveis por promover a determinação e diferenciação das células musculares vêm sendo identificados (Weintraub et al., 1991). O primeiro gene a ser clonado foi o fator miogênico MyoD (Pinney \& Emerson, 1992), e estudos subseqüentes revelaram que este é parte de uma família de quatro genes relacionados: MyoD, Myf-5, miogenina e MRF4.

Em estudos conduzidos em codornas selecionadas para crescimento acelerado foi observado um atraso na formação dos somitos e na ativação dos fatores miogênicos durante 0 desenvolvimento embrionário. Estes estudos indicam a possibilidade de manipulação do desenvolvimento muscular de animais através da modulação da expressão dos fatores miogênicos. (Coutinho et al., 1993).

Em experimentos de microcirurgia (Pownall et al., 1996) foi demonstrado que o afastamento do complexo tubo neural/notocorda dos somitos recentemente formados é capaz de inibir a ativação de fatores miogênicos envolvidos no processo de determinação e diferenciação do tecido muscular esquelético, como o fator miogênico MyoD. Esse afastamento provoca um atraso na ativação de tais fatores. Sendo assim, se nestas condições ocorrer maior determinação de células precursoras de tecido muscular, assim como foi detectado em codornas, esse atraso poderia então possibilitar que células precursoras de tecido muscular continuassem a proliferar. Consequentemente, um maior número de células poderiam, então, formar fibras musculares proporcionando maior quantidade de massa muscular no animal adulto.

Neste contexto, o presente trabalho teve como objetivo investigar 0 efeito da manipulação do complexo tubo neural/notocorda no padrão de expressão do fator miogênico $M y o D$ e na proliferação celular durante a miogênese em embriões de galinha. Tais estudos adicionais poderão vir a 
elucidar os mecanismos de ação do complexo tubo neural/notocorda durante a formação da musculatura esquelética fornecendo uma ferramenta auxiliar extremamente valiosa nos programas de melhoramento genético e gerando subsídios para um aumento da capacidade de crescimento do tecido muscular nas aves. 


\section{REVISÃO DE LITERATURA}

\subsection{Músculo}

A musculatura tem como unidade celular a fibra muscular. Um aumento no diâmetro (hipertrofia) ou no número (hiperplasia) das fibras musculares resulta em um aumento na massa muscular. Em adultos, a hipertrofia das fibras é o principal processo envolvido no aumento da musculatura esquelética, visto que praticamente não ocorre um aumento no número de fibras após o nascimento de mamíferos e aves. O exercício físico pode aumentar o diâmetro de fibras musculares, no entanto, este procedimento exige atividade física intensa, requer dieta rica em energia e proteína e é bastante ineficiente na conversão de ração em proteína muscular. (revisado por Mitchell \& Burke, 1995; Pinney \& Emerson, 1992).

Uma alternativa para se produzir animais com mais músculo seria aumentar, durante a fase embrionária, o número de fibras musculares. Estudos conduzidos por Coutinho et al., (1993) revelaram que, em linhagens de codorna que apresentam um aumento no número de fibras musculares, existe um atraso na formação de somitos, na ativação de fatores miogênicos e na expressão de miosina.

\subsection{Formação do Músculo Esquelético}

O desenvolvimento da musculatura esquelética é determinado por um conjunto de alterações moleculares, celulares e morfológicas que tornaram-se 
modelo para a compreensão da complexa rede molecular que atua desde a determinação da linhagem de células musculares dentro do conjunto de células embrionárias até a completa maturação da fibra muscular (Ludolph \& Konieczny, 1995).

Nos vertebrados, a musculatura esquelética é derivada dos somitos, que são esferas epiteliais transientes no mesoderma paraxial que flanqueia o tubo neural. Inicialmente, o somito é composto de células colunares arranjadas radialmente ao redor de um pequeno lúmen. (Christ \& Ordahl, 1995; Rawls \& Olson,1997).

Em uma etapa subseqüente, os somitos compartimentalizam-se em três domínios celulares distintos, esclerótomo, miótomo e dermátomo. Inicialmente, a região ventral do somito forma o esclerótomo, do qual as costelas e vértebras são derivadas. A região dorsal forma uma camada epitelial conhecida como dermomiótomo, que contém células precursoras de músculo esquelético e derme. Esta se diferencia e forma o dermátomo e o miótomo.

As células do dermomiótomo medial dão origem aos músculos das costas e musculatura intercostal (musculatura epaxial), enquanto que as células da porção lateral originam os músculos da parede ventral do corpo e dos membros (musculatura hipaxial) (Maroto et al., 1997; Ordahl \& LeDouarin, 1992; Rawls \& Olson, 1997; Tajbakhsh et al., 1997).

Embora a origem embrionária das células musculares esteja relativamente clara, a rede molecular que controla a população de células precursoras miogênicas e os eventos de diferenciação celular ainda não foram bem definidos (Ludolph \& Konieczny, 1995).

Existe uma rede de fatores que modulam a miogênese, seja de uma maneira positiva através da ativação de genes músculo-específicos relacionados a proteínas musculares, assim como modulando o processo de uma maneira 
negativa, impedindo eventos como a determinação e diferenciação das células miogênicas (revisado por Arnold \& Winter, 1998).

Dentro dos fatores que ativam a miogênese está a família MyoD, da qual fazem parte MyoD, myf-5, miogenina e MRF4. Dentre eles, o fator MyoD foi o primeiro a ser identificado (Weintraub et al., 1991). Os quatro fatores estão relacionados com a ativação do programa miogênico, porém, suas funções durante a miogênese são distintas. MyoD e Myf-5 parecem ter funções redundantes na especificação dos mioblastos, enquanto que miogenina e MRF4 são necessários para os eventos de diferenciação (Emerson, 1993). Em codorna, o primeiro gene a ser ativado é o MyoD, seguido por Myf-5 e miogenina (Coutinho, et al., 1993; Pownall \& Emerson, 1992). Análises de hibridação "in situ" realizadas no Laboratório de Biotecnologia Animal (ESALQ/USP) demonstraram que, também em frango de corte, o fator miogênico MyoD é ativado cedo no processo de miogênese (Gabriel et al., 2000). Em estudo recente foi sugerido que os níveis de Myf-5, em animais onde foi bloqueada a expressão dos outros três fatores, são insuficientes para ativar o programa miogênico na ausência de MyoD, MRF4 e miogenina (Valdez et al., 2000). Os fatores da família MEF2 parecem estar relacionados com a atividade da miogenina, aumentando e mantendo sua expressão (Ludolph \& Konieczny, 1995). A proteína Pax-3 tem sido identificada como um importante regulador da miogênese, podendo ativar a expressão de MyoD, Myf-5 e miogenina (Arnold \& Winter, 1998; Maroto et al., 1997). A proteína LIM parece estar relacionada a diferenciação celular (Arber et al.,1994; Kong et al., 1997; Ludolph \& Konieczny, 1995).

Em adição, existem fatores capazes de interferir negativamente no programa miogênico, garantindo que os fatores ativadores sejam expressos no local e momento apropriados. Dentre eles estão os fatores de crescimento FGF ("Fibroblast Growth Factor") e TGF- $\beta$ ("Transforming Growth Factor- $\beta$ ) que são 
descritos como potentes inibidores de diferenciação (Dauncey \& Gilmour, 1996; Emerson, 1993). Um novo gene da família dos TGF- $\beta$, o GDF-8 também conhecido como miostatina foi recentemente clonado (McPherron et al., 1997). Este gene é expresso durante o desenvolvimento embrionário e no músculo esquelético adulto. Estudos de deleção gênica revelaram que ele age como um regulador negativo do desenvolvimento da musculatura esquelética. Outro gene envolvido é o Id que está relacionado à inibição da diferenciação (revisado por Sasson et al., 1993). Mais recentemente foi identificada a proteina Mist1 que parece funcionar como um regulador negativo da atividade do MyoD (Lemercier et al., 1998). Um resumo dos principais eventos e fatores regulatórios envolvidos na miogênese e diferenciação celular, foi elaborado por Dauncey \& Gilmour, 1996) e está reproduzido na figura 1. 


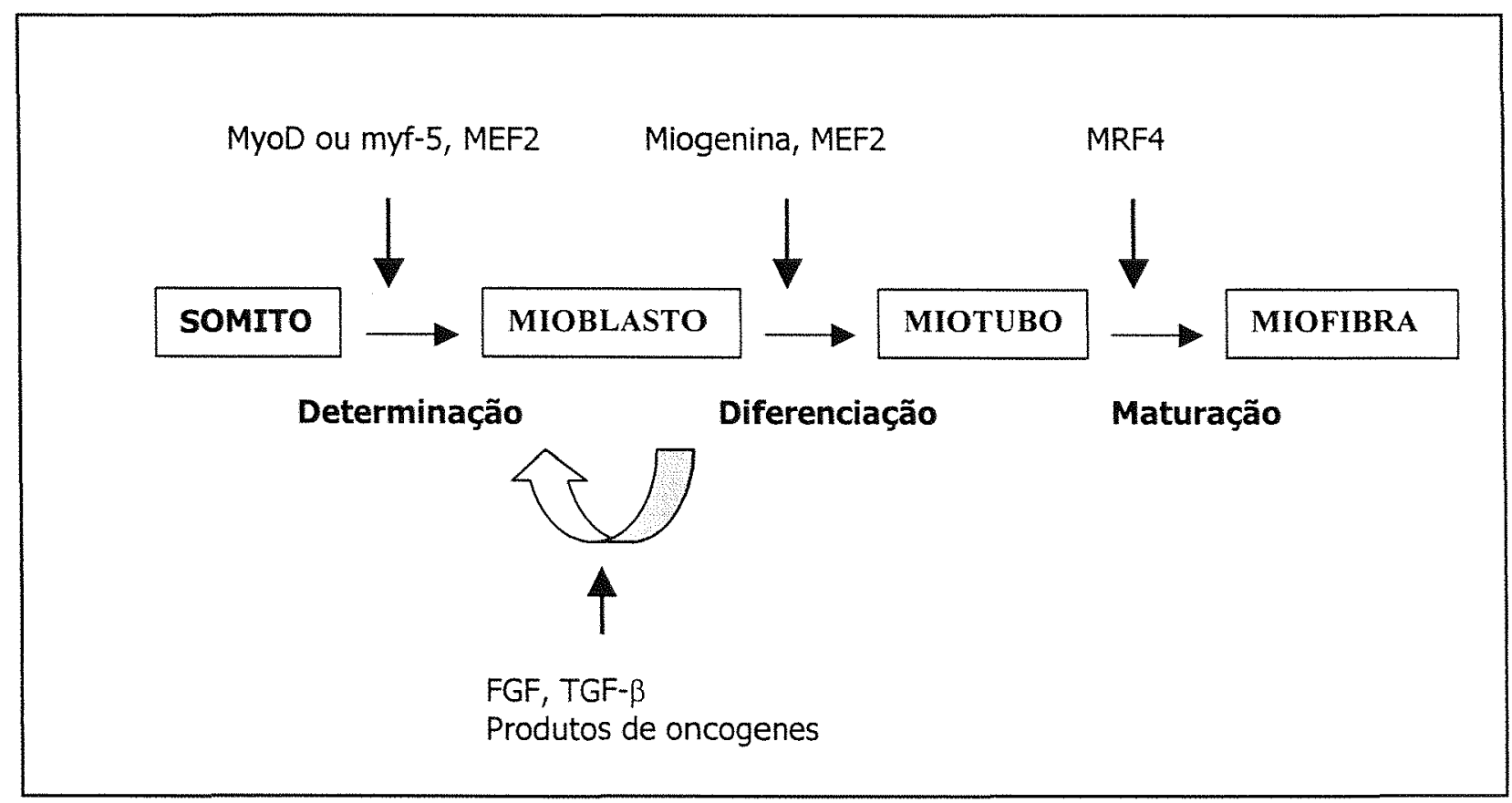

Figura 1. Perfil dos principais eventos e fatores regulatórios envolvidos na miogênese e diferenciação (Dauncey \& Gilmour, 1995).

\subsection{Influência das estruturas axiais na miogênese}

O papel que as estruturas axiais exercem na formação do tecido muscular esquelético, bem como na determinação e manutenção da expressão de fatores regulatórios miogênicos tem sido bastante investigado. (Buffinger \& Stockdale, 1994; Emerson, 1993; Pinney \& Emerson, 1992; Rong et al. 1992).

$O$ processo de indução de células dos somitos para a formação de músculo parece ser dependente de sinais oriundos do tubo neural. Estudos conduzidos por Rong et al., (1992) revelaram que somitos imaturos, quando afastados do tubo neural não formam células musculares. Porém, quando estes somitos são reaproximados do tubo neural, observa-se a formação de células musculares. 
O tubo neural exerce uma função regulatória positiva na diferenciação do miótomo em embriões de aves. Experimentos de transplante das estruturas axias, revelaram que o destino das células que irão formar o miótomo, dermátomo e esclerótomo pode ser redefinido por mudanças nas posições de tais células nos somitos em relação ao tubo neural. (Emerson, 1993; Ordahl \& Le Douarin, 1992). Dentro deste contexto, resultados obtidos por Pownall et al. (1996) mostraram que sinais provenientes do complexo tubo neurall/notocorda controlam os processos de ativação e manutenção da expressão de MyoD e myf-5 nas células progenitoras do miótomo, logo após a formação dos somitos e antes da diferenciação do miótomo. Esses resultados confirmam a importante influência das estruturas axiais (tubo neural/notocorda) no processo de miogênese em aves.

Em adição, estudos de cultura de somitos na presença ou ausência de estruturas axias, revelaram que o tubo neural é necessário para a indução da miogênese em somitos recentemente formados. Foi proposto que os sinais combinados das estruturas axiais (tubo neural/notocorda/placa basal) são requeridos para a indução da expressão de fatores miogênicos. (Münsterberg \& Lassar, 1995; Stern \& Hauschka, 1995). Da mesma forma, Gamel, et al. (1995) demonstraram que o agrupamento de mioblastos em culturas de tecido é influenciado pela presença ou ausência de órgãos axiais.

Estudos recentes relataram que sinais indutivos emanam do tubo neural, notocorda e ectoderma. Destes estudos concluiu-se que as funções do tubo neural e notocorda sugerem que eventos epigenéticos levando à miogênese são mais complexos do o previsto. Os sinais vindos da placa lateral contrapõem-se aos dos órgãos axiais e induzem a migração de células precursoras de músculo. (Brand-Saberi \& Christ, 1999).

Os estudos relatados reforçam a importância das estruturas axias na determinação e manutenção do programa miogênico em embriões de aves, 
além de mostrar sua influência na expressão dos fatores regulatórios miogênicos. Porém, são necessários estudos futuros no sentido de elucidar como as moléculas sinalizadoras e seus receptores interagem no processo de formação do músculo esquelético no embrião.

\subsection{Proliferação celular e MyoD}

As fibras musculares esqueléticas dos vertebrados são formadas por fusão celular dos mioblastos progenitores, células embrionárias que tem potencial para proliferação.

O crescimento e diferenciação dos mioblastos é controlado por fatores extra-celulares, especialmente fatores de crescimento assim como FGF e TGF- $\beta$. $\mathrm{Na}$ presença desses fatores, os mioblastos proliferam, enquanto que em uma concentração reduzida dos mesmos, os mioblastos podem sair do ciclo celular, fundir e diferenciar em fibras contráteis (Dauncey \& Gilmour, 1996; Ludolph \& Konieczny, 1995; Pinney \& Emerson, 1992).

O fator miogênico MyoD desempenha função como regulador da divisão celular mioblástica. Sendo assim, o MyoD controla a interrupção a divisão celular mioblástica e a iniciação da diferenciação em resposta à diminuição dos fatores de crescimento (Pinney \& Emerson, 1992).

Estudos conduzidos por Langman \& Nelson(1968), revelaram que as células do miótomo não se dividem e que o processo de multiplicação celular ocorre no dermátomo. É interessante observar que em cultura de tecidos, a expressão de MyoD inibe a proliferação celular, no entanto tal relação não foi investigada nas células dos somitos de embriões. Em adição, Yablonka-Reuveni et al., (1999) mostraram que células em cultura isoladas de ratos, nos quais foi feita a deleção do gene MyoD, não ocorreu inibição e as células continuaram a proliferar. Tais estudos sugerem que a presença do fator miogênico MyoD é fundamental para a progressão normal das células para a diferenciação. 


\section{$2.5 \mathrm{BrdU}$}

O BrdU (bromodeoxiuridina), um análogo da timidina, é incorporado ao DNA durante a fase $S$ do ciclo celular, e é bastante utilizado na marcação de células em proliferação. Posteriormente, o BrdU pode ser detectado em cortes histológicos pelo uso de anticorpos conjugados a enzimas ou agentes fluorescentes. (Garret \& Guthrie, 1998; Gratzner, 1982; Schutte et al., 1987).

Um dos aspectos importantes na detecção do BrdU em cortes histológicos é o tipo de fixador utilizado. Estudos desenvolvidos por Lopes et al., (2000) revelaram que um ponto essencial para a otimização do método foi a fixação do material por apenas uma hora em paraformaldeído $4 \%$.

As análises imunohistoiquímicas, baseadas na incorporação e detecção do BrdU, têm sido aplicadas na identificação de células em proliferação (Alfei et al., 1993; Garret \& Guthrie, 1998; Lopes et al., 2000; Veronese et al., 1989), assim como para o estudo da cinética celular em tumores malígnos (Kikuiama et al., 1988).

Desta forma, a utilização deste sistema pode fornecer informações extremamente importantes sobre os processos fundamentais da formação dos tecidos embrionários. 


\section{MATERIAL E MÉTODOS}

\subsection{Incubação dos ovos e coleta dos embriões}

Os ovos de galinha da linhagem Ag Ross provenientes da Granja Ninho Verde (Tietê-SP) foram incubados a $37.9^{\circ} \mathrm{C}$ por 48 horas. Após a incubação os embriões foram coletados com auxílio de discos de papel filtro e estadiados de acordo com Hamburger \& Hamilton (1951), no estádio $\mathrm{HH} 12$ de desenvolvimento.

\subsection{Microcirurgia para afastamento e reaproximação dos somitos do tubo neural/notocorda}

Após retirados dos ovos, os embriões foram submetidos à microcirurgia com o uso de agulhas para a separação dos três últimos somitos e parte do mesoderma paraxial não segmentado do complexo tubo neural notocorda. Foram, então, mantidos a $37^{\circ} \mathrm{C}$ em meio de cultura $(0,36 \% \mathrm{NaCl}, 1,0 \%$ ágar, $50 \%$ clara fina) por 12 a 16 horas em ambiente úmido. Em seguida foram fixados em paraformaldeído $4 \%$ a $40 \mathrm{C}$ por 16 horas e desidratados em etanol $70 \%$. Para a reaproximação, embriões que foram incubados por 12-16 horas tiveram seus somitos colocados em contato com o tubo neural através de um ponto com agulha e linha de microcirurgia. Os embriões reaproximados foram incubados por mais 8 horas e então fixados. 


\subsection{Obtenção e preparação da sonda}

A sonda de RNA antisense de MyoD usada foi obtida pela técnica de RTPCR (do inglês, reverse transcription - polymerase chain reaction) descrita por Bales et al., 1993. Foi extraído RNA total de embriões de 48 horas como reportado por Chomcyznski \& Sacchi, 1987. Uma micrograma de RNA total foi utilizada nas reações de transcrição reversa para obtenção do DNA complementar (CDNA). Após a desnaturação da amostra por 10 minutos a $70^{\circ} \mathrm{C}$, o tampão de PCR $[2,5 \mathrm{mM} \mathrm{MgCl} 2,1 \mathrm{mM}$ dNTPs, $50 \mathrm{ng}$ de primer oligo (dT) (Gibco) e 200 unidades da enzima transcriptase reversa Superscript II (Gibco)] foram adicionados para um volume final de $20 \mu \mathrm{l}$. As amostras foram incubadas por 50 minutos a $42^{\circ} \mathrm{C}$, em seguida, foi feita a inativação da trancritase reversa por aquecimento (15 minutos a $70^{\circ} \mathrm{C}$ ), seguida pelo tratamento com uma unidade de RNAse $\mathrm{H}$ por 20 minutos a $37^{\circ} \mathrm{C}$, para degradar as fitas de RNA. Dez por cento do volume total da reação de cDNA foi amplificado diretamente por reação em cadeia da polimerase (PCR).

Os primers usados para as amplificações foram descritos por Lin-Jones \& Hauschka (1996), com exceção de que o primer reverso foi desenhado de uma combinação da seqüência do gene MyoD complementar com a seqüência do promotor bacteriófago 77 em sua extremidade $5^{\prime}$ (bases sublinhadas). Este primer também teve três bases (GGG) correspondentes ao sítio de transcrição inicial para as reações de transcrição in vitro. As seqüências direta e reversa foram 5'-TACCCAGTGCTGGAGCACTA-3'

e $5^{\prime}-$ TAATACGACTCACTATAGGGGTCTTGGAGCTTGCTGAAC-3', respectivamente.

A reação em cadeia da polimerase (PCR) foi feita usando uma concentração final de $10 \mathrm{pmol}$ de primers, $10 \mathrm{mM}$ de cada dNTP, $1.5 \mathrm{mM} \mathrm{MgCl} 2$ e 2 unidades da enzima Taq DNA polimerase (Gibco/BRL) em um volume final de $50 \mu$ l. O protocolo de amplificação consistiu de 35 ciclos de denaturação a $95^{\circ} \mathrm{C}$ por 1 minuto, anelamento dos primers a $57^{\circ} \mathrm{C}$ por 1 minuto e extensão a 
$74^{\circ} \mathrm{C}$ por 1 minuto. O produto amplificado de $493 \mathrm{pb}$ foi separado em gel de agarose, purificado em uma coluna (Quiagen) e usado nas reações de transcrição in vitro. Aproximadamente $200 \mathrm{ng}$ de produto purificado foram incubados por 2 horas a $370 \mathrm{C}$ com UTP marcado com digoxigenina e 40 unidades da enzima 77 RNA polimerase (Boehringer Mannheim). A sonda antisense do MyoD (470 pb) foi submetida a hidrólise alcalina em 2 volumes de tampão carbonato $\left(60 \mathrm{mM} \mathrm{Na}_{2} \mathrm{CO}_{3}, 40 \mathrm{mM} \mathrm{NaHCO}\right.$, $\mathrm{pH}$ 10.2) por 5 minutos a $60^{\circ} \mathrm{C}$ para reduzir seu tamanho e aumentar seu acesso aos tecidos. A hidrólise foi interrompida por adição de igual volume de solução de neutralização (1 M Tris- $\mathrm{HCl}, \mathrm{pH} 8.0$, contendo $1.5 \mathrm{M} \mathrm{NaCl}$ ). Os fragmentos hidrolisados foram precipitados em $70 \mu \mathrm{g}$ de glicogênio/ml e 3 volumes de etanol. A sonda de RNA antisense de MyoD marcada com digoxigenina foi estocada em solução de hibridação (50\% formamida, 4X SSC, 1X Denhardt's solution, 0,5 $\mu \mathrm{g} / \mu \mathrm{l}$ DNA de esperma de salmão desnaturado, $0,25 \mu \mathrm{g} / \mu \mathrm{l}$ tRNA de levedura e $10 \%$ dextran sulfate) $a-70^{\circ} \mathrm{C}$.

\subsection{Hibridação "in situ"}

A técnica foi utilizada de acordo com Coutinho et al., 1992 e foi aplicada nos embriões após a microcirurgia.

Primeiramente, foi feita a desidratação dos embriões com etanol 80, 95 e $100 \%$ por 2 minutos cada, seguida de mais uma desidratção com etanol $100 \%$ por 5 minutos, todas à temperatura ambiente e sob plataforma de agitação. Foi feita então, a lavagem em solução contendo $50 \%$ xileno/50\% etanol por 5 minutos, seguida de lavagem em xileno por 30 minutos. Após isso, foram feitas 5 lavagens rápidas em etanol $100 \%$, seguida de hidratação em etanol 95, 80 e 70\% por 2 minutos cada à temperatura ambiente.

Os embriões foram lavados em PBS $(0,14 \mathrm{M} \mathrm{NaCl}, 2,7 \mathrm{mM} \mathrm{KCl}, 10 \mathrm{mM}$ $\mathrm{Na}_{2} \mathrm{HPO}_{4}, 1,8 \mathrm{mM} \mathrm{KH} 2 \mathrm{PO}_{4}, \mathrm{pH}$ 7.4) + Triton X-100 (PBT.3) e digeridos em 
$30 \mu \mathrm{g} / \mathrm{ml}$ de proteinase $\mathrm{K}$ por 2 a 5 minutos a $37^{\circ} \mathrm{C}$. Em seguida, os embriões foram lavados novamente em PBT.3 e incubados por 10 minutos em 50\% solução de hibridação/ 50\% PBT.3. Depois foram pré-hibridados em $100 \mu$ l de solução de hibridação por 3 horas a $63^{\circ} \mathrm{C}$. A hibridação foi feita em uma nova solução contendo uma sonda de RNA antisenso de MyoD marcada com digoxigenina (concentração final $0,3 \mu \mathrm{g} / \mathrm{ml}$ ) por 45 horas a $63^{\circ} \mathrm{C}$. Em seguida, foram feitas lavagens com solução de hibridação (sem a sonda) por 5minutos, 2,5 e 16 horas a $63^{\circ} \mathrm{C}$. Após isso, os embriões foram lavados em $80 \%$ solução de hibridação (Hib.)/20\% PBT.3, 60\% Hib./40\% PBT.3, 40\% Hib./60\% PBT.3, $20 \%$ Hib./80\% PBT.3 por 20 minutos cada à temperatura ambiente. Seguindose por 2 lavagens em PBT. 3 por 1 hora cada à temperatura ambiente.

A detecção imunológica foi feita com um anticorpo anti - digoxigenina conjugado à fosfatase alcalina em uma diluição de 1:2000. O sinal dos transcritos do fator miogênico MyoD foi detectado por uma reação colorimétrica com substratos cromatogênicos $[4,5 \mu$ de NBT (nitroblue tetrazolium) $75 \mathrm{mg} / \mathrm{ml}$ e 3,5 $\mu \mathrm{l}$ de X-phosphate (5-bromo-4-chloro-3-indolyl phosphate) $50 \mathrm{mg} / \mathrm{ml}$ ] como descrito no Kit Genius System (Boehringer Manheim). A reação de desenvolvimento de cor foi feita por 8 horas e interrompida pela incubação em tampão TE (Tris $\mathrm{HCl} 10 \mathrm{mM}$, pH 8.0, EDTA $1 \mathrm{mM}$ ). Os embriões foram fotografados usando lupa Leica WILD MPS52 e estocados em TE a $4^{\circ} \mathrm{C}$.

\subsection{Marcação das células em proliferação com BrdU}

Após a microcirurgia, os embriões foram retirados do meio de cultura a $37^{\circ} \mathrm{C}$, lavados brevemente por 1 minuto em PBS $(0,14 \mathrm{M} \mathrm{NaCl}, 2,7 \mathrm{mM} \mathrm{KCl}$, $10 \mathrm{mM} \mathrm{Na}_{2} \mathrm{HPO}_{4}, 1,8 \mathrm{mM} \mathrm{KH_{2 }} \mathrm{PO}_{4}$, $\mathrm{pH}$ 7.4), transferidos para placa de petry contendo PBS $1 \mathrm{X}+50 \mu \mathrm{M}$ de BrdU e mantidos a $37^{\circ} \mathrm{C}$ por 60 minutos em banho-maria sob agitação. Após esse período, foram retirados os embriões vivos (com batimentos cardíacos) e lavados 2 vezes em PBS a $37^{\circ} \mathrm{C}$ por 15 minutos 
cada. Os embriões foram então fixados em paraformaldeído $4 \%$ por 60 minutos a $4^{\circ} \mathrm{C}$ e em seguida desidratados em etanol $70 \%$.

\subsection{Preparação de cortes histológicos}

Os embriões desidratados em etanol $70 \%$ passaram por mais duas desidratações em etanol 90 e $100 \%$ por 5 minutos cada à temperatura ambiente. Foi feita a infiltração da resina plástica JB4 (Polysciences) nos embriões pela colocação dos mesmos em uma solução contendo $50 \%$ solução A ( $+0,5 \%$ de catalisador), $50 \%$ etanol sob agitação a $4^{\circ} \mathrm{C}$ por 60 minutos. Foram feitas então, as trocas por igual volume de solução A por mais 2 vezes de 60 minutos, 16 horas, seguidas de 4 trocas de 30 minutos e mais 16 horas, todas a $4^{\circ} \mathrm{C}$ sob agitação. Para o emblocamento os embriões foram colocados em moldes plásticos e foi adicionada solução $A+B(25: 1)$, em seguida a cavidade foi coberta com parafilm para impedir a aeração e facilitar a polimerização da resina por um período de 16 horas. Os blocos contendo os embriões foram retirados dos moldes e colados em blocos de madeira (suportes para a colocação no micrótomo). Os cortes histológicos foram feitos em micrótomo (LEICA) com espessura de $8 \mu \mathrm{m}$, colocados em lâminas de vidro e levados à placa aquecida ( 45 a $50^{\circ} \mathrm{C}$ ) para a adesão dos cortes à lâmina.

\subsection{Imunodetecção do BrdU nos cortes}

Os cortes aderidos às lâminas de vidro foram incubados em TS $(0,05 \mathrm{M}$ Tris- $\mathrm{HCl}, 0,1 \mathrm{M} \mathrm{NaCl}, \mathrm{pH} 8.0)$ contendo pronase $(10 \mu \mathrm{g} / \mathrm{ml})$, a $37^{\circ} \mathrm{C}$ por 30 minutos. A inativação da pronase foi feita a $65^{\circ} \mathrm{C}$ por 10 minutos seguida da incubação em tampão glicina $(0,5 \mathrm{M}, \mathrm{pH} 2.0)$ por 10 minutos à temperatura ambiente. Após isso foi feita fervura em tampão citrato $(10 \mathrm{mM})$ em microondas por 5 minutos, seguidos de 5 minutos fora do microondas e mais 5 minutos de fervura. As lâminas foram mantidas por $30 \mathrm{~min}$. em tampão citrato quente e 
depois lavadas em PBT $0,1 \%$ (PBS+ $0,1 \%$ de Triton $\mathrm{X}-100$ ) por 10 minutos à temperatura ambiente. $O$ excesso de umidade foi removido com papel filtro. Foram então adicionados sobre o corte 50-60 $\mu$ de tampão de incubação (66 $\mathrm{mM}$ Tris, 0,66 $\mathrm{mM} \mathrm{MgCl} 2,1 \mathrm{mM}$ 2-mercaptoetanol) contendo anticorpo anti-BrdU (1:10), coberto com parafilm e mantido a $37^{\circ} \mathrm{C}$ por 30 minutos. A lâmina foi lavada 2 vezes em PBT $0,1 \%$ por 15 minutos cada à temperatura ambiente. Mais uma vez foi removido o excesso de umidade com papel filtro e então adicionados sobre o corte $50-60 \mu \mathrm{l}$ de PBT $0,1 \%$ contendo anticorpo anticamundongo conjugado à fosfatase alcalina (1:10), coberto com parafilm e mantido a $37^{\circ} \mathrm{C}$ por 30 minutos. A lâmina foi lavada novamente 2 vezes com PBT $0,1 \%$ por 15 minutos cada à temperatura ambiente. $O$ excesso de umidade foi removido com papel filtro para ser iniciada a detecção colorimétrica do BrdU. O substrato utilizado foi NBT/X-phosphate (nitroblue tetrazolium/5-bromo-4chloro-3-indolyl phosphate). nas concentrações de $50 \mathrm{mg} / \mathrm{ml}$ de $X$-phosphate e $75 \mathrm{mg} / \mathrm{ml}$ de NBT, em TSM (0,1 M Tris- $\left.\mathrm{HCl}, 0,1 \mathrm{M} \mathrm{NaCl}, 0,05 \mathrm{M} \mathrm{MgCl}_{2}, \mathrm{PH} 9.5\right)$. O desenvolvimento do sinal foi realizado em ambiente escuro.

\subsection{Extração de RNA total}

Foi extraído o RNA total dos somitos que se formaram após a microcirurgia (lado afastado) e dos somitos do lado contralateral (controle). Após a remoção dos tecidos, foram acrescentados aos mesmos $375 \mu \mathrm{l}$ Trizol + $125 \mu \mathrm{l} \mathrm{H}_{2} \mathrm{O}$ DEPC, seguindo-se incubação por 5 minutos a $15-30^{\circ} \mathrm{C}$. Foram acrescentados, então, $100 \mu l$ de clorofórmio, procedendo-se agitação vigorosa por 15 segundos. Após 2 minutos à temperatura ambiente, as amostras foram centrifugadas a $4^{\circ} \mathrm{C}, 12000 \times \mathrm{g}$ por 15 minutos. A fase aquosa foi removida e transferida para outro tubo, onde foi feita a precipitação do RNA adicionando-se $250 \mu \mathrm{l}$ de isopropanol. Após 10 minutos à temperatura ambiente, procedeu-se nova centrifugação a $4^{\circ} \mathrm{C}, 12000 \times \mathrm{g}$ por $10 \mathrm{~min}$. O "pellet" resultante foi lavado em $500 \mu \mathrm{l}$ de etanol $75 \%$ e centrifugado a $4^{\circ} \mathrm{C}, 7500 \times \mathrm{g}$ por 5 minutos. 
Depois de completamente seco, o RNA foi ressuspendido em $11 \mu \mathrm{l}$ de $\mathrm{H}_{2} \mathrm{O}_{\text {DEPC }}$ (água ultrafiltrada $+0.01 \%$ de dietilpirocarbonato).

\subsection{Síntese de CDNA e RT-PCR Quantitativo}

A técnica de RT-PCR quantitativo consiste da utilização de um competidor interno da reação de PCR que trata-se de um DNA heterólogo, de menor tamanho, porém com os mesmos sítios de ligação aos primers que 0 cDNA nativo. Sendo assim, espera-se que os CDNAs nativos e competidor sejam amplificados com a mesma eficiência, uma vez que cada um deles compete igualmente pela amplificação. Para a síntese de competidores para MyoD e $\beta$ actina utilizados no presente trabalho, uma deleção de $50 \mathrm{pb}$ foi gerada no cDNA de MyoD e 90pb no cDNA de $\beta$-actina.

$1 \mu \mathrm{g}$ de RNA total foi utilizado para a síntese de cDNA com primer oligo (dT). As amostras de RNA contendo primer $(0,5 \mu \mathrm{g} / \mu \mathrm{l})$, foram aquecidas a $70^{\circ}$ C por 10 minutos, para eliminação de possiveis estruturas secundárias. Após este intervalo, as amostras foram imediatamente transferidas para gelo, onde permaneceram por pelo menos 1 minuto, antes da reação com a transcritase reversa.

A reação para a síntese do cDNA foi feita num volume total de $20 \mu$, contendo $1 \times$ tampão de PCR, 2,5 mM MgCl $2,1 \mathrm{mM}$ de cada dNTP e 200 unidades da enzima Transcritase Reversa Superscript II (Gibco/BRL). Após 50 minutos a $42^{\circ} \mathrm{C}$, procedeu-se a inativação da enzima por aquecimento (15 minutos a $70^{\circ} \mathrm{C}$ ). Para liberar as moléculas de CDNA do RNA usado como molde, as amostras foram tratadas com 1 unidade de RNAse $\mathrm{H}$ por 20 minutos a $37^{\circ} \mathrm{C}$, antes da reação de PCR. Para a amplificação de $\beta$-actina e MyoD foram empregados $2 \mu \mathrm{l}$ de cDNA nas reações de PCR contendo $10^{-3}$ fmoles e $10^{-6}$ fmoles de DNA competidor para $\beta$-actina e MyoD, respectivamente em 1x tampão de PCR, $1,5 \mathrm{mM} \mathrm{MgCl} 2,10$ pM dos "primers" direto (marcado com 
fluoresceína) e reverso, $10 \mathrm{mM}$ dos dNTPs e 2 unidades de Taq I DNA polimerase. O volume final das reações foi de $25 \mu \mathrm{l}$. Para a amplificação de $\beta$ actina foi feita desnaturação inicial a $95^{\circ} \mathrm{C}$ por 3 minutos, seguindo-se temperatura de $55^{\circ} \mathrm{C}$ para anelamento e $74^{\circ} \mathrm{C}$ para extensão. Os parâmetros utilizados para MyoD foram os mesmos, com exceção da temperatura de anelamento, que foi alterada para $57^{\circ} \mathrm{C}$. O número de ciclos para amplificação de $\beta$-actina e MyoD foi respectivamente de 20 e 35 . Os produtos de PCR foram separados e quantificados em seqüenciador automático ("Automated Laser Fluorescent DNA Sequencer - A.L.F.'TM, Pharmacia). Após a eletroforese, os picos dos produtos nativo e competidor foram integrados pelo software Fragment Manager ${ }^{T M}$ (Pharmacia), que permite analisar 0 tamanho dos fragmentos por comparação com o marcador de tamanho molecular, bem como quantificar as respectivas áreas de pico.

De acordo com Tsai \& Wiltbank (1996), para a construção das curvaspadrão, as áreas dos picos correspondentes ao amplicon nativo e competidor foram calculadas, plotando-se, então, a proporção logarítmica dos amplicons nativo e competidor (Log nativo/competidor) contra o logarítimo da concentração molar de DNA nativo (Log nativo) adiciona às reações. Através da equação da reta produzida por regressão linear, a concentração de $\beta$-actina e MyoD foi determinada de cada amostra-teste. 


\section{RESULTADOS E DISCUSSÃO}

\subsection{Expressão do fator miogênico MyoD em embriões de galinha}

Foram realizados experimentos com a finalidade de estudar o padrão de expressão do fator miogênico MyoD em embriões inteiros. A figura 2 apresenta a expressão do fator miogênico MyoD em um embrião de galinha no estádio 12 de desenvolvimento. O sinal obtido na hibridação da sonda de RNA antisenso de MyoD é caracterizado pela coloração vermelha observada na região dos somitos. Pode-se verificar que o fator MyoD é expresso na região proximal dos

somitos, adjacente ao tubo neural. A expressão é mais intensa nos somitos mais maduros próximos à cabeça e vai diminuindo nos somitos mais jovens, próximos à região caudal do embrião. 


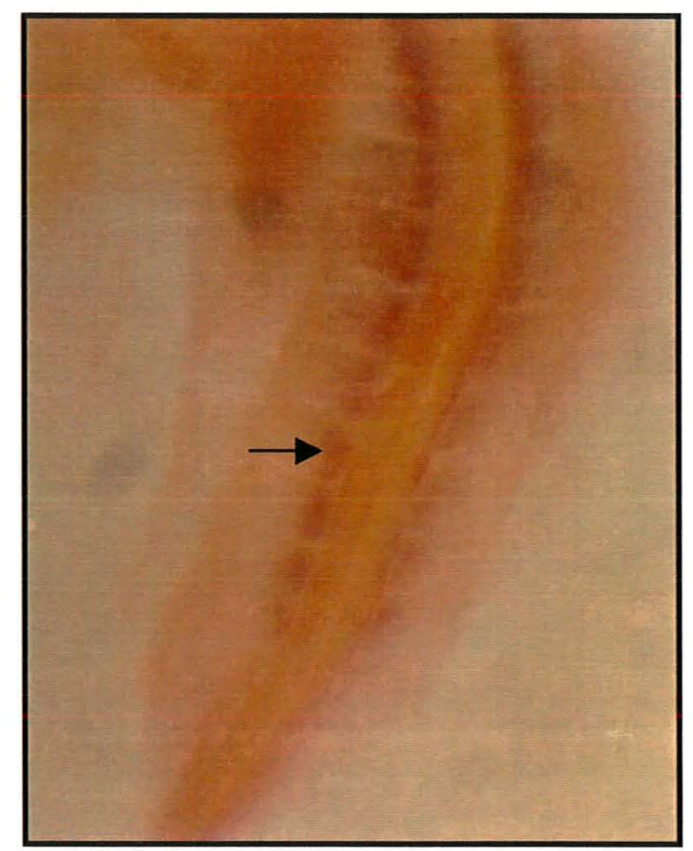

Figura 2. Fotomicrografia de um embrião de galinha (estádio 12). A expressão do fator miogênico MyoD está localizada nos somitos (seta).

Estudos anteriores relataram que em embriões de codorna o fator QmyoD é o primeiro gene a ser ativado na cascata transcricional dos genes bHLH (básicos hélice - volta - hélice) durante a formação dos somitos (Coutinho et al., 1993; Pownall \& Emerson, 1992, Pownall et al., 1996). O fator QmyoD começa a ser expresso em todos os somitos, principalmente nos mais anteriores e vai aumentando ao longo do eixo anterior-posterior do embrião.

O padrão de expressão do fator miogênico MyoD é similar em embriões de galinha e codorna (Gabriel et al., 2000). Em somitos recentemente formados, os trasncritos de MyoD foram detectados na região mediana dos somitos. Os resultados obtidos no presente estudo confirmam tais observações indicando que o fator miogênico MyoD desempenha papel importante na manutenção da miogênese. 


\subsection{Influência do tubo neural e notocorda na expressão de MyoD}

Com o intuito de investigar o mecanismo de ativação do fator miogênico MyoD, estudo foram feitos envolvendo a separação dos três últimos somitos e parte do mesoderma paraxial não segmentado das estruturas axiais (tubo neural e notocorda). A operação realizada está esquematizada na figura 3 e o resultado da expressão de MyoD na figura 4.

O fator miogênico MyoD não foi ativado no lado submetido à microcirurgia (lado direito) durante o período de 12 a 16 horas após a manipulação, porém ocorreu a formação dos somitos, sugerindo que as estruturas axiais não interferem nesse processo (figura 4). O sinal observado no lado não afastado estava localizado na região do somito, proximal ao tubo neural.

Esses resultados sugerem uma função das estruturas axiais (tubo neural/notocorda) relacionada ao controle e manutenção do padrão de expressão do fator miogênico MyoD em embriões de galinha, dessa maneira, corroborando resultados descritos em estudos anteriores. Dentre eles, alguns estudos envolvendo microcirurgia para separação das estruturas axiais (tubo neural e notocorda) dos somitos têm mostrado a existência de sinais vindos dessas estruturas envolvidos na diferenciação dos somitos (Brand-Saberi et al., 1993; Goulding et al., 1994; Pourquie et al., 1993; Pownall et al., 1996).

Pownall et al., 1996, utilizando a técnica de hibridação "in situ' desenvolvida por Coutinho et al., 1992, observaram que não houve expressão do fator miogênico QmyoD (análogo ao MyoD em embriões de galinha) nos somitos afastados do complexo tubo neural/notocorda em embriões de codorna após manipulação cirúrgica. 


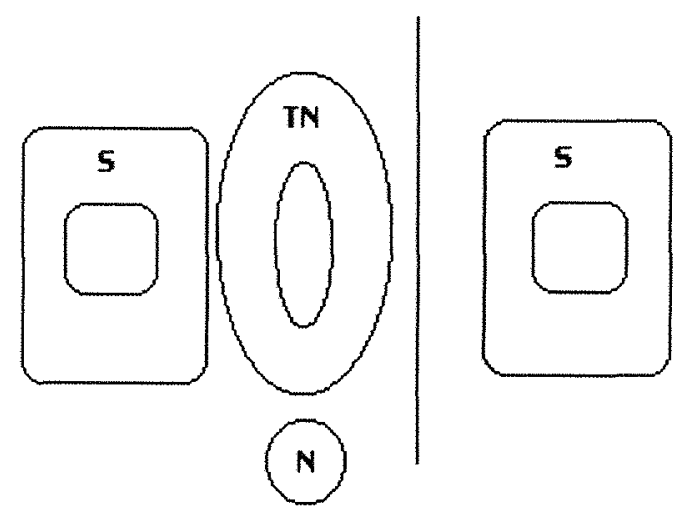

Figura 3 - Esquema do procedimento usado na microcirurgia para afastamento dos somitos (S) do complexo tubo neural/notocorda (TN, N).

Similarmente, Dietrich et al., 1998 realizaram a separação do tubo neural/notocorda do mesoderma paraxial em embriões de galinha, com uma incisão vertical. O processo de segmentação ocorreu normalmente. Em relação à expressão de MyoD, houve perda da mesma 6,5-9,5 horas após a cirurgia.

$\mathrm{Na}$ figura 4 A-B são apresentados os resultados do procedimento utilizado para o afastamento dos somitos do complexo tubo neural/notocorda. Pode-se verificar o padrão de expressão do fator miogênico MyoD 12 a 16 horas após a manipulação cirúrgica (figura $4 \mathrm{C}$ ).

Dietrich et al., 1997 realizaram a remoção completa do tubo neural adjacente aos somitos XIII e IX em embriões de galinha no estádio 10-13. Foi observado que as placas segmentares de ambos os lados aproximaram-se uma da outra, fundindo-se sobre a notocorda. Da mesma maneira, as metades do ectoderma fundiram-se, fechando a incisão após 24 horas. Em ambos os casos o fator miogênico MyoD foi expresso normalmente, assim como Pax 3 e Pax 1. 
Contraditoriamente aos resultados do presente estudo, Bober et al., (1994) reportaram que a expressão de MyoD e a diferenciação do miótomo são independentes das estruturas axiais.

\subsection{Reaproximação dos somitos e complexo tubo neural/notocorda}

Para confirmar a influência do complexo tubo neural/notocorda na ativação do fator miogênico MyoD, foi preciso investigar se a reaproximação das estruturas permite que o processo de miogênese seja reiniciado. Para isso, agulhas com fio de nylon foram utilizadas para reaproximar os somitos do tubo neural. Após a reaproximação por 12 a 16 horas, foi observado que o fator miogênico MyoD voltou a ser expresso nos somitos que tinham sido afastados, como mostra a figura $4 \mathrm{D}$. Tais resultados confirmam a influência das estruturas axiais (tubo neural e notocorda) na ativação do fator miogênico MyoD em embriões de galinha. Resultados semelhantes foram observados por Pownall et al. (1996), utilizando embriões de codorna.

Além disso, tais resultados demonstram que os somitos formados a partir do mesoderma paraxial não segmentado nas 12 a 16 horas após a manipulação cirúrgica não perdem a capacidade de responder aos sinais das estruturas axiais.

Em adição, Münsterberg \& Lassar, 1995 conduziram estudos "in vitro", onde os três somitos mais caudais (I-III de embriões de galinha no estádio 12) foram cultivados na ausência ou presença do complexo tubo neural/placa basal/notocorda. Quando esses somitos foram cultivados por 5 dias na ausência das estruturas axiais, os transcritos de MyoD, myf-5, miogenina e miosina não foram detectados. Em contraste, os somitos do lado contralateral do mesmo embrião foram cultivados na presença das estruturas axiais, ocorrendo a expressão dos fatores miogênicos MyoD e myf-5, bem como miogenina e miosina. 


\subsection{Análise da expressão de MyoD com o uso da RT-PCR}

O sinal encontrado utilizando a técnica de hibridação "in situ" foi localizado na região proximal ao tubo neural e mediana dos somitos. Porém, trata-se de uma técnica qualitativa, o que não possibilita a quantificação do nível de expressão do MyoD. Nesse sentido, utilizou-se a técnica de RT-PCR (do inglês, "reverse transcription-polymerase chain reaction") com a finalidade de quantificar a expressão do fator miogênico MyoD nos embriões submetidos à microcirurgia. O RT-PCR é uma técnica bastante sensivel que permite detectar genes específicos em pequenas amostras de tecido. 

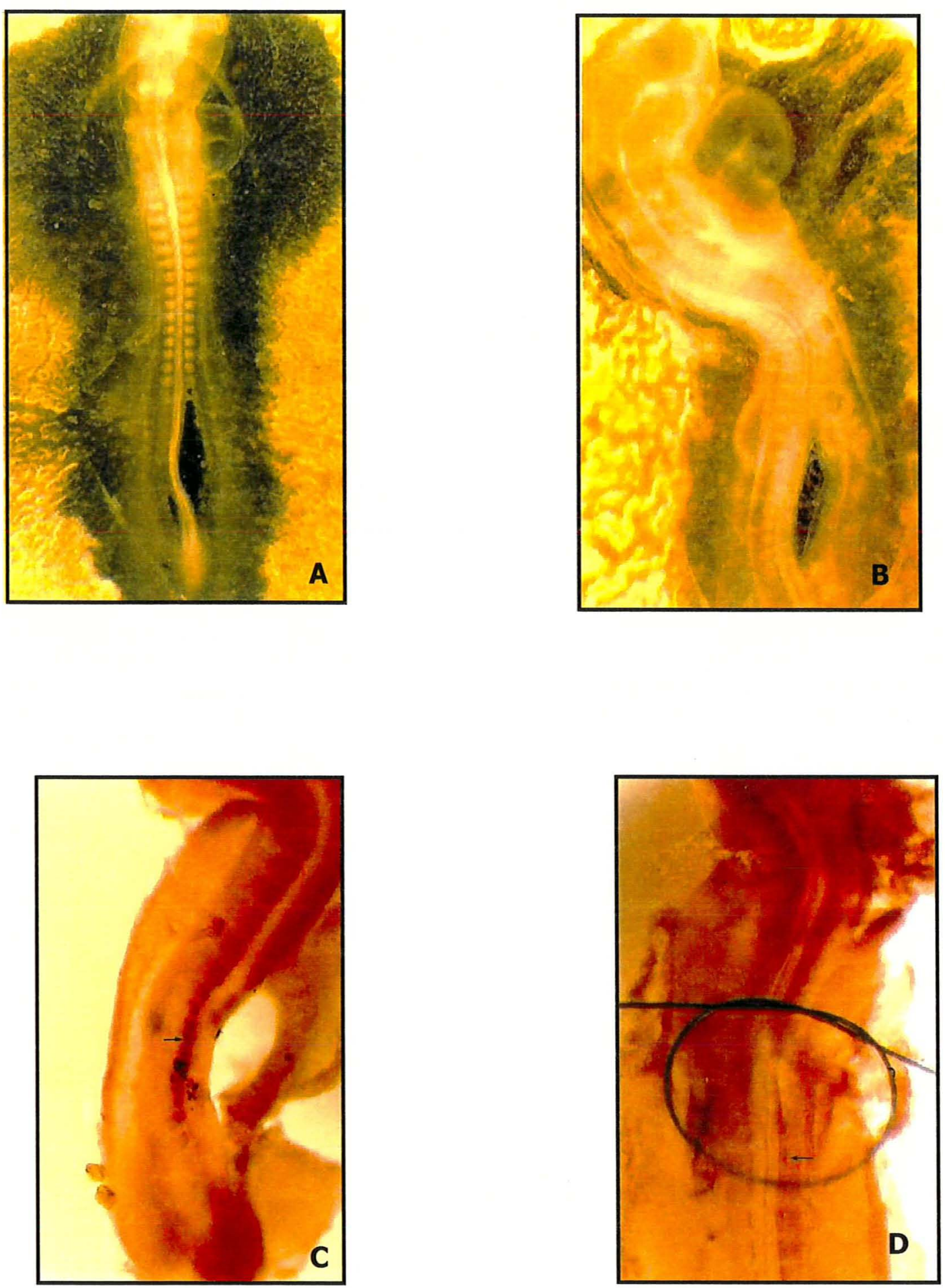

Figura 4. Efeito da manipulação do complexo tubo neural/notocorda na expressão de MyoD. A) Separação dos somitos e placa segmentar do tubo neural/notocorda em 
embrião no estádio 12. B) Embrião 12 a 16 horas após a manipulação cirúrgica. C) Expressão de MyoD por hibridação "in situ" 12 a 16 horas após manipulação cirúrgica (seta). D) Expressão de MyoD após reaproximação dos somitos e tubo neural/notocorda (seta).

Na tabela 1 são apresentados os resultados obtidos com o uso da RTPCR. Observou-se que, nos embriões submetidos à microcirurgia, a expressão de MyoD foi 17,7 vezes menor no lado afastado em relação ao lado não afastado (controle). De acordo com o teste " $t$ " de Student a diferença entre as médias foi significativa a nível de $5 \%$. A técnica foi aplicada com êxito, porém, os resultados correspondem a apenas três embriões analisados. Portanto, tornase necessária a realização de experimentos adicionais, envolvendo uma quantidade maior de embriões para a obtenção de resultados mais representativos.

A expressão de $\beta$-actina foi utilizada para normalizar as amostras quanto à eficiência na extração de RNA e síntese de cDNA. Observou-se que no lado afastado (microcirurgiado), a expressão foi praticamente 1,5 vezes menor em relação ao lado não afastado. Uma possivel explicação para isso, seria a existência de fatores tróficos vindos do tubo neural e crista neural, relacionados com a regulação da capacidade proliferativa da população de células miogênicas. (Bober et al., 1994; Pourquié et al., 1995).

Nas figuras 5 e 6 estão representadas informações referentes aos géis de poliacrilamida feitos no seqüenciador ALF, nos quais os tamanhos das bandas apresentam fragmentos que representam os genes MyoD competidor (421 pb) e nativo (471 pb) - figura 5, e $\beta$-actina nativo (409 pb) e competidor (319 pb) - figura 6. 
Tabela 1 - Quantificação da expressão do fator miogênico MyoD em embriões de galinha submetidos à microcirurgia. $n=$ número de embriões.

\begin{tabular}{|c|c|c|c|c|}
\hline EMBRIÕES & $\mathrm{n}=3$ & [] MyoD & [ ] $\beta$-actina & MyoD corrigido \\
\hline & 1 & 0.22 & 0.34 & 0.65 \\
\hline LADO & 2 & 0.65 & 0.42 & 1.55 \\
\hline CONTROLE & 3 & 0.92 & 0.95 & 0.96 \\
\hline Média & & 0.60 & 0.57 & $1.06^{\mathrm{Ab} *, * *}$ \\
\hline & 1 & 0.00 & 0.06 & 0.00 \\
\hline LADO & 2 & 0.08 & 0.45 & 0.17 \\
\hline AFASTADO & 3 & 0.00 & 0.59 & 0.00 \\
\hline Média & & 0.03 & 0.37 & $0.06^{\mathrm{AB}}$ \\
\hline
\end{tabular}

\subsection{Proliferação celular em embriões submetidos à microcirurgia}

O músculo esquelético nos vertebrados origina-se dos somitos e mesoderma paraxial não segmentado como conseqüência de sinais indutores recebidos do complexo tubo neural/notocorda, Buffinger \& Stockdale (1994). Esses sinais exercem influência na diferenciação celular, de maneira que as células cessam a proliferação. Com o intuito de verificar a influência do afastamento do complexo tubo neural/notocorda (microcirurgia) na proliferação celular foi utilizado o $\mathrm{BrdU}$, um análogo da timidina que se incorpora nas células na fase $S$ do ciclo celular. As células que incorporaram o BrdU foram identificadas pela formação de um sinal escuro no núcleo.

A figura 7 apresenta o corte transversal de um embrião não submetido à cirurgia, no qual pode-se observar a proliferação celular no tubo neural, notocorda e somito. As células em proliferação no tubo neural, apresentaram-se 
dispostas centralmente, confirmando, dessa maneira resultados obtidos por Lopes et al. (2000).

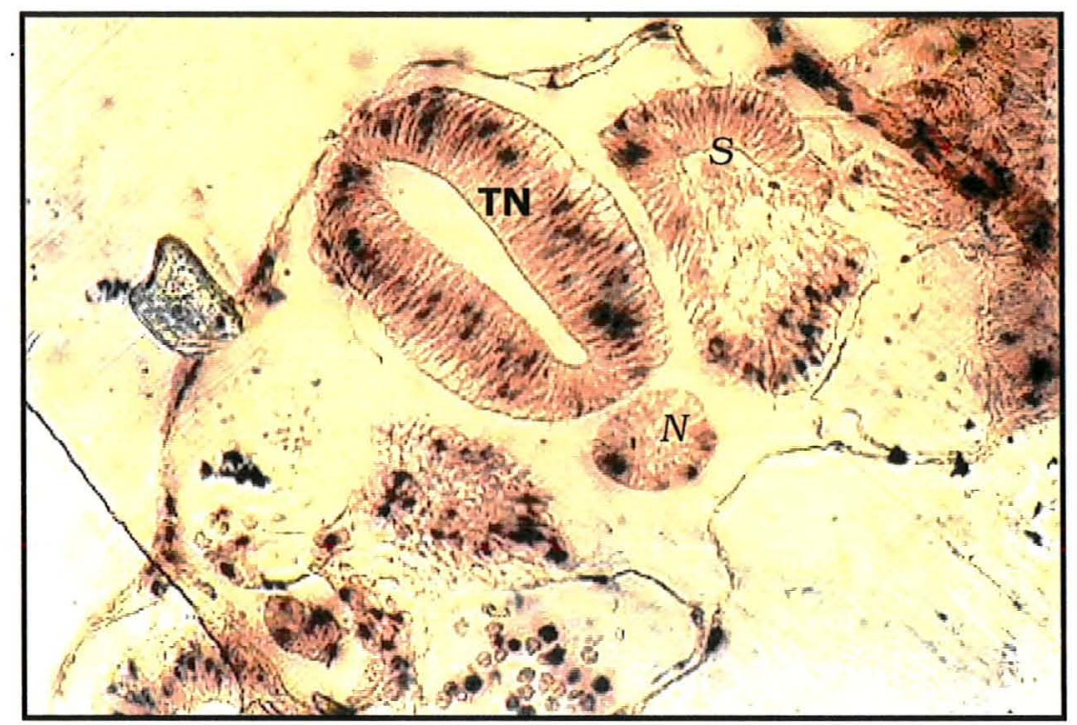

Figura 7. Corte transversal de um embrião de galinha no estádio 12 mostrando as células em proliferação. $\mathrm{TN}=$ tubo neural; $\mathrm{N}=$ notocorda e $\mathrm{S}=$ somito.

Os embriões submetidos à microcirurgia apresentaram marcação mais intensa na região do dermátomo do que no miótomo, ou seja, a proliferação celular foi mais intensa na região do dermátomo. Ainda em relação à proliferação celular, houve diferença no número de células do lado afastado quando comparado ao lado não afastado (controle). Observou-se também, que os somitos no lado afastado eram menores e com um aspecto irregular da disposição das células. (Figura 8). 


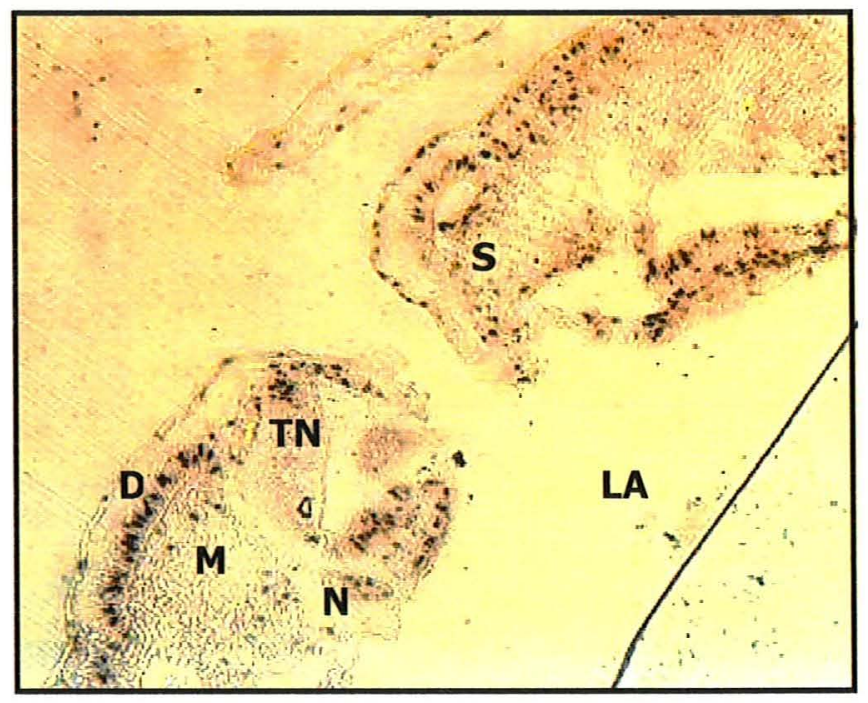

Figura 8. Corte transversal de um embrião de galinha submetido à microcirurgia. $\mathrm{TN}=$ tubo neural; $\mathrm{N}=$ notocorda; $\mathrm{S}=$ somito; $\mathrm{D}=$ dermátomo; $\mathrm{M}=$ miótomo; $\mathrm{LA}=$ lado afastado.

Um dos aspectos observados foi o menor número aparente de células em proliferação na região de formação do somito afastada do tubo neural pela microcirurgia, quando comparado ao somito em contato com o complexo tubo neural/notocorda (tabela 2). Pode ser que o afastamento do tubo neural tenha causado uma redução no número de células em proliferação na região do somito. Esses resultados confirmam o papel que as estruturas axiais exercem na proliferação e diferenciação das células durante a formação dos somitos. 
Tabela 2. Número de células em proliferação em embriões de galinha submetidos a microcirurgia (cortes transverais).

\begin{tabular}{c|c|c}
\hline EMBRIÃO & $\begin{array}{c}\text { CONTROLE } \\
\text { (nº de células) }\end{array}$ & $\begin{array}{c}\text { AFASTADO } \\
\left(\mathbf{n}^{\circ} \text { de células) }\right.\end{array}$ \\
\hline 1 & 30 & 22 \\
\hline 2 & 33 & 13 \\
\hline 3 & 18 & 19 \\
\hline MEDIA & $\mathbf{2 7}$ & $\mathbf{1 8}$ \\
\hline
\end{tabular}

A hipótese inicial deste trabalho de que um atraso na ativação dos fatores miogênicos pode permitir que células dos somitos continuem a proliferar por mais tempo, levando a um aumento no número de células precursoras de tecido muscular não foi confirmada. Na verdade, os resultados obtidos mostraram que quando afastadas do tubo neural as células dos somitos continuam a proliferar, porém o número de células do lado afastado foi menor em relação ao controle (não afastado). Por outro lado, houve a perda da expressão do fator miogênico MyoD nos somitos afastados o que confirma o atraso na ativação dos fatores miogênicos. 


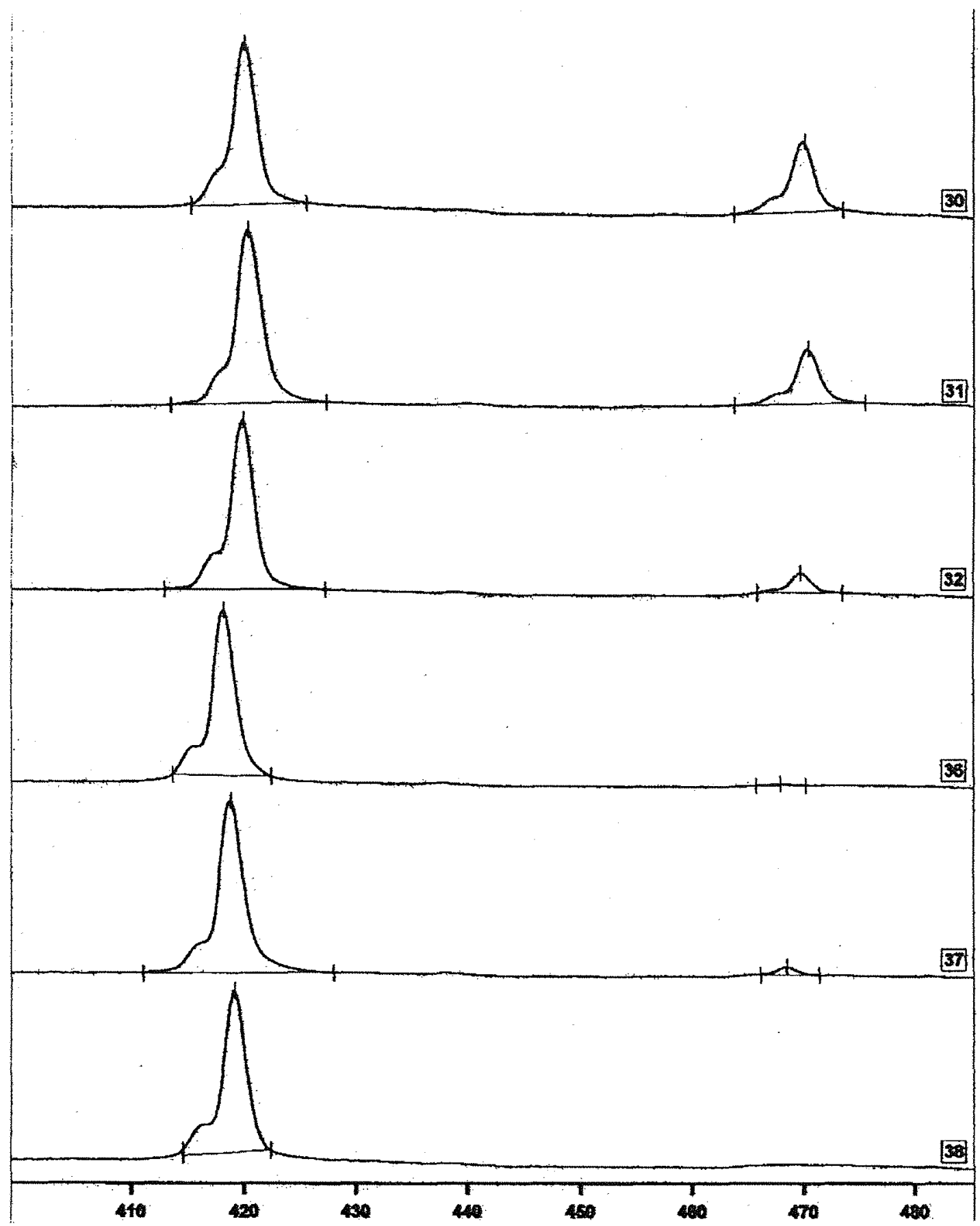

Figura 5. Cromatograma obtido após eletroforese em sequenciador automático, mostrando os picos resultantes da coamplificação de $2 \mu \mathrm{l}$ de cDNA (MyoD nativo) 
com $1 \times 10^{-6}$ de DNA competidor. Somitos de embriões controle (canaletas $30-$ 32) e afastados do tubo neural (canaletas $36-38$ ).

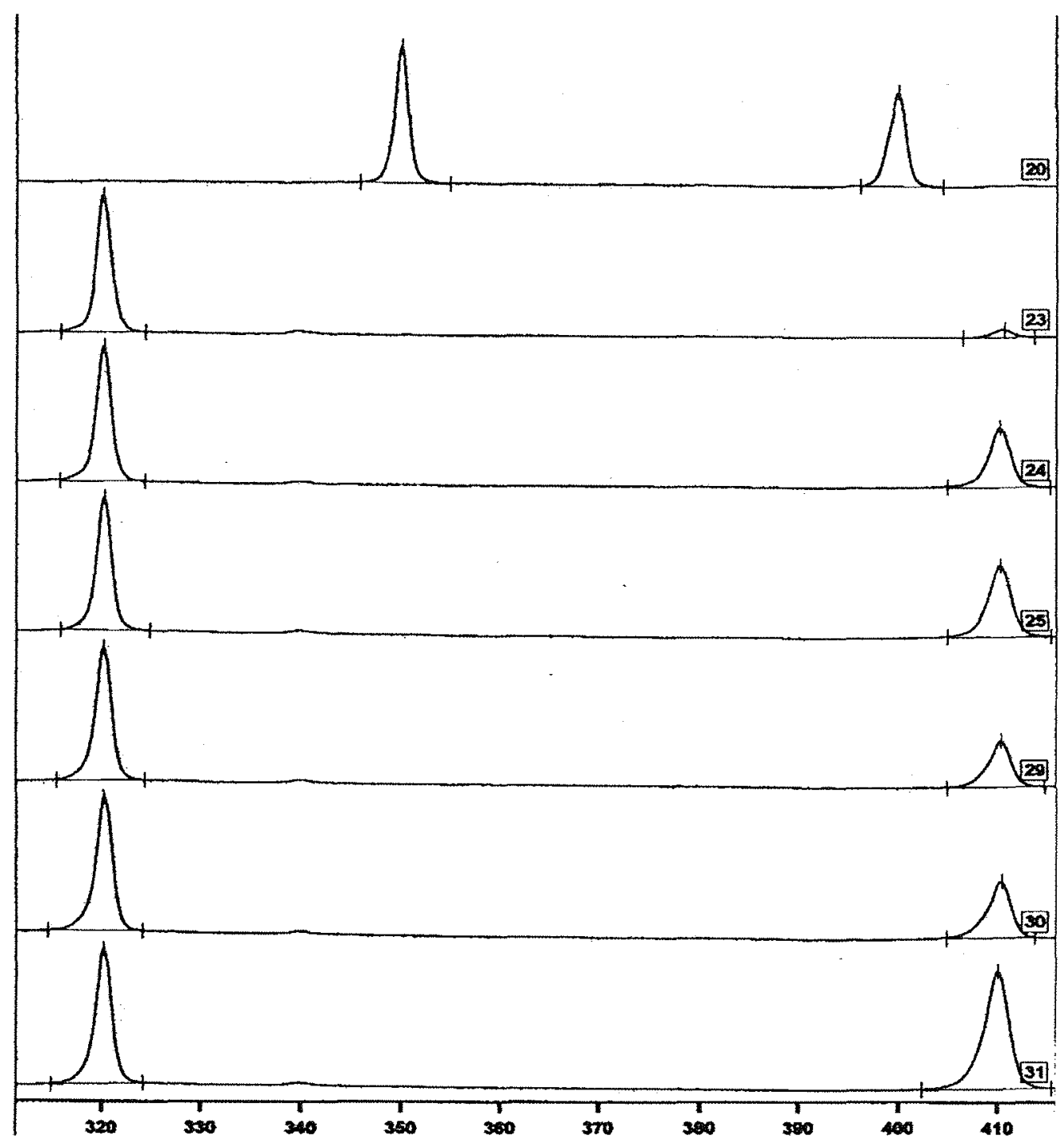

Figura 6. Cromatogrma obtido após eletroforese em sequenciador automático, mostrando os picos resultantes da coamplificação de $2 \mu \mathrm{l}$ de cDNA ( $\beta$-actina nativo) com $1 \times 10^{-3}$ de DNA competidor. Somitos de embriões afastados do tubo 
neural (canaletas 23 - 25) e controle (canaletas 29 - 31). Canaleta 20 é o marcador de peso molecular. 


\section{CONCLUSÕES}

O fator miogênico MyoD é expresso na região proximal dos somitos, adjacente ao tubo neural.

Foi confirmado que nos somitos afastados do complexo tubo neural/notocorda não ocorre a expressão do fator miogênico MyoD.

A reaproximação das estruturas permite que a expressão do fator miogênico MyoD ocorra novamente.

Em relação à proliferação celular, as células dos somitos afastadas do complexo tubo neural/notocorda, continuaram a proliferar, porém, em número menor em relação ao lado controle. 


\section{REFERÊNCIAS BIBLIOGRÁFICAS}

ALFEI, L.; COLOMBARI, P.T.; CAVALLO, D.; ELEUTERI, P.; DE VITA, R. Use of 5 -bromodeoxyuridine immunohistochemistry to examine proliferative activity of tissues. European Journal of Histhochemistry, v.37, n.2, p.183-189, 1993.

ARBER, S.; HALDER, G.; CARONI, P. Muscle LIM protein, a novel essential regulator of myogenesis, promotes myogenic differentiation. Cell, v.79, n.2, p.221-31, 1994.

ARNOLD, H.H; WINTER, B. Muscle differentiation: more complexity to the network of myogenic regulators. Current Opinion in Genetics and Development, v.8, n.5, p.539-44, 1998.

BOBER, E.; BRAND-SABERI, B.; EBENSPERGER, C. WILTING, J. BALLING, R.; PATERSON, B.M.; ARNOLD, H.-H.; Christ, B. Initial steps of myogenesis in somites are independent of influence from axial strutures. v.120, p.30733082, 1994. 
BRAND-SABERI, B.; EBENSPERGER, C.; WILTING, J.; BALLING, R.; CHRIST, B. The ventralizing effect of the notochord on somite differentiation in chick embryos. Anatomy and Embryology, v.188, p.239-245, 1993.

BRAND-SABERI, B.; CHRIST, B. Genetic and epigenetic control of muscle development in vertebrates. Cell and Tissue Research, v.296, n.1, p.199212, 1999.

BUFFINGER, N.; STOCKDALE, F.E. Myogenic specification in somites: induction by axial strutures. Development, v.120, p.1443-1452, 1994.

CHOMCZYNSKI, P.; SACCHI, N. Single step method of RNA isolation by acid guanidinium thiocyanate-phenol-chloroform extration. Analytical Biochemistry, v.162, p.156-9, 1987.

CHRIST, B.; ORDHAL, C.P. Early stages of chick somite development. Anatomy and Embryology, v.191, p.381-396. 1995.

COUTINHO, L.L.; MORRIS, J.; IVARIE, R. Whole mount in situ detection of low abundance transcripts of the myogenic factor qmf1 and myosin heavy chain protein in quail embryos. Biotechniques, v.13, n.5, p.722-724, 1992. 
COUTINHO, L.L.; MORRIS, J.; MARKS, H.L.; BUHR, J.R. , \& IVARIE, R. Delayed somite formation in a quail line exhibiting myofiber hyperplasia is accompanied by delayed expression of myogenic regulatory factors and myosin heavy chain. Development, v.117, p.563-569. 1993.

DAUNCEY, M.J.; GILMOUR, R.S. Regulatory factors in the control of muscle development. Proceedings of the Nutrition Society. v.55, p.543-559. 1996.

DIETRICH, S.; SCHUBERT, F.R.; LUMSDEN, A. Control of dorsoventral pattern in the chick paraxial mesoderm. Development, v.124, p.3895-3908, 1997.

DIETRICH， S.; SCHUBERT, F.R.; HEALY, C.; SHARPE, P.T.; LUMSDEN, A. Specification of the hypaxial musculature. Development, v.125, p.22352249, 1998.

EMERSON, C.P. Skeletal myogenesis: genetics and embryology to the fore. Current Opinion in Genetics and Development, v.3, p.265-274, 1993.

GABRIEL, J.E.; ALVES, H.J.; ALVARES, L.E.; SCHMIDT, G.S.; COUTINHO, L.L. In situ detection of transcripts of the myogenic factor MyoD in whole chicken embryos. Genetics. and Molecular Biology, v.23, n.1, p.145-148, 2000.

GAMEL, A.J.; BRAND-SABERI, B.; BODO, C. Halves of epithelial somites and segmental plate show distinct muscle differentiation behavior in vitro 
compared to entire somites and segmantal plate. Developmental Biology, v.172, p.625-639, 1995.

GARRET, W.M.; GUTHRIE Detection of bromodeoxyuridine in paraffin-embedded tissue sections using microwave antigen retrieval is dependent on the mode of tissue fixation. Biochemica, n.1, p.17-20, 1998.

GOULDING, M.; LUMSDEM, A.; PAQUETTE, A.J. Regulation of Pax-3 expression in the dermomyotome and its role in muscle development. Development, v.120, p.957-971, 1994.

GRATZNER, H.G. Monoclonal antibody to 5-bromo and 5-iodo-deoxyuridine: a new reagent for detection of DNA replication. Sciences, v.218, p.474-475, 1982.

HAMBURGER, V.; HAMILTON, H.L. A series of normal stages in the development of the chick embryo. Journal of Morphology, v.88, p.49-92, 1951.

KIKUYAMA, S.; KUBOTA, T.; WATANABE, M. ISHIBIKI, K.; ABE, O. Cell kinectic study of human carcinomas using bromodeoxyuridine. Cell and Tissue Kinetics, v.21, p.15-20, 1988.

KONG, Y.; FLICK, M.J.; KUDLA, A.J. et al. Muscle LIM protein promotes myogenesis by enhancing the activity of MyoD. Molecular and Cellular Biology, v.17, n.8, p.4750-60, 1997. 
LANGMAN, J.; NELSON, G.R. A radioautograph study of the development of the somite in the chick embryo. Journal of Embryology and Experimental Morphology, v.19, n.2, p.217-226. 1968.

LEMERCIER, C.; TO, R.Q.;CARRASCO, R.A.; KONIECZNY, S.F. The basic helixloop-helix transcription factor Mist1 functions as a transcriptional repressor of myoD. Embo Journal , v.17, n.5, p.1412-22, 1998

LIN-JONES, J.; HAUSCHKAT, S. Myogenic determination factor expression in the developing avian bud: an RT-PCR analysis. Developmental Biology, v.174, p.407-422, 1996.

LOPES, M.L.; SCHIMDT, G.S.; COUTINHO, L.L. Identification of proliferating cells in chicken embryos through 5-bromo-2'-deoxyuridine immunohistochemical detection. Genetics and Molecular Biology, 2000. /no prelo/.

LUDOLPH, D.C.; KONIECZNY, S.F. Transcription factor families: muscling in on the myogenic program. The FASEB Journal, v.9, p.1595-1604, Dec. 1995.

MAROTO, M.; RESHEF, R.; MÜSNSTERBERG, A.E.; KOESTER, S.; GOULDING, M.; LASSAR, A.B. Ectopic Pax-3 activates MyOD and Myf-5 expression in embryonic mesoderm and neural tissue. Cell, v.89, n.4, p.139-148, Apr. 1997. 
MCPHERRON, A.C.; LAWLER, A.M.; LEE, S.-J. Regulation of skeletal muscle mass in mice by a new TGF- $\beta$ superfamily member. Nature, v.387, p.83-90, 1997.

MITCHELL, R. D.; BURKE, W.H. Genotype and sexual influences on growth and muscle development of chicken embryos. Growth, Development \& Aging, v.59, p.31-44,1995.

MÜNSTERBERG, A.E.; LASSAR, A.B. Combinatorial signals from neural tube, floor plate and notochord induce myogenic bHLH gene expression in the somite. Development, v.121, p.651-660, 1995.

ORDAHL, C.P.; LE DOUARIN, N.M. Two myogenic lineages in the development somite. Development, v.14, p.339-352. 1992.

PINNEY, D.; EMERSON, C. Skeletal muscle differentiation. In: RUSSO, V.E.A.; BRODY, S.; COVE, D.; OTTOLENGHI, S. Development: the molecular genetic approach. Berlim: Springer-Verlag, 1992. cap.31, 459-78.

POURQUIE, O.; COLTEY, M.; TEILLET, M.-A.; ORDAHL,C.; LE DOUARIN, N.M. Control of dorsoventral patterning of somitic derivatives by notochord and floor plate. Proceedings of National Academy of Sciences of USA, v.90, p.5242-5246, 1993. 
POURQUIE, O.; COLTEY, M.; BREANT, C.; LE DOURAIN, N.M. Control of somite patternig by signals from the lateral plate. Proceedings of National Academy of Sciences of USA, v.92, p.3219-3223, 1995.

POWNALL, M.E.; EMERSON, C.J. Sequential activation of three myogenic regulatory genes during somite morphogenesis in quail embryos. Developmental Biology, v.151, n.1, p.67-79. 1992.

POWNALL, M.E.; STRUNK, K.E.; EMERSON, C.P. Nothocord signals control the transcriptional cascade of myogenic bHLH genes in somites of quail embryos. Development, v.122, p.1475-1488. 1996.

RAWLS, A.; OLSON, E.N. MyoD meets its maker. Cell, v.89, n.4, p.5-8, Apr. 1997.

RONG, P.M.; TEILLET, C.; LE DOUARIN, N.M. The neural tube /nothocord complex is necessary for vertebral but not limb and body wall striated muscle differentiation. Development, v.115, p.657-672. 1992.

SASSON, D.A. Myogenic regulatory factors: dissecting their role and regulation during vertebrate embryogenesis. Developmetal Biology, v.156, p.11-23, 1993.

SCHUTTE, B.; REYNDERS, M.M.J.; BOSMAN, F.T.; BLIJHAM, G.H. Effect of tissue fixation on anti-bromodeoxyuridine immunohistochemistry. The journal of Histochemistry and Cytochemistry, v.35, n.11, p.1343-1345, 1987. 
STERN, H.M.; HAUSCHKA, S.D. Neural tube and notochord promote in vitro myogenesis in single somite explants. Developmental Biology, v.167, p.87-103, 1995.

TAJBAKHSH, S.; ROCANCOURT, D.; COSSU, G.; BUCKINGHAM, M. Redefining the genetic hierarchies controlling skeletal myogenesis: Pax-3 and myf-5 act upstream of MyoD. Cell, v.89, n.4, p.127-138. Apr.1997.

TSAI, S.; WILTBANK, M.C. Quantification of mRNA using competitive RT-PCR with standard curve methodology. Biotechniques, v.21, p.862-866, 1996.

VALDEZ, M.R.; RICHARDSON, J.A.; KLEIN, W.H.; OLSON, E.N. Failure of Myf5 to support myogenic differentiation without myogenin, MyoD, and MRF4. Developmental Biology, v. 219, n.2, p.287-98, 2000.

VERONESE, S.; GAMBACORTA, M. FALINI, B. In situ demonstration of tissue proliferative activity using anti-bromo-deoxyuridine monoclonal antibody. Journal of Clinical Pathology, v. 42, n.8, p.820-826, 1989.

WACHTLER, F.; CHRIST, B. The basic embriology of skeletal muscle formation in vertebrates: the avian model. Developmental Biology, v.3, p.217-227, 1992.

WEINTRAUB, H.; DWARKI, V.J.; VERMA, I.; DAVIS, R.; HOLLENBERG, S.; SNIDER, L.; LASSAR, A.; TAPSCOTT, S.J. Muscle-especific transcriptional activation by MyoD. Genes Development, v.5, n.8, p.1377-86.1991. 
YABLONKA-REUVENI, Z.; RUDNICKI, M.A.; RIVERA, A.J.; PRIMIG, M.; ANDERSON, J.E.; NATANSON, P. The transition from proliferation to differentiation is delayed in satellite cells from mice lacking MyoD. Developmental Biology, v.210, p.440-455, 1999. 


\section{APÊNDICE}

\section{Apêndice 1}

\section{PROTOCOLO EXPERIMENTAL DA TÉCNICA DE HIBRIDIZAÇÃO "IN SITU".}

Este protocolo foi inicialmente descrito por Coutinho et al. (1992).

Dia 1. Incubação dos ovos de galinha por aproximadamente 48 horas a $39^{\circ} \mathrm{C}$.

Dia 2. Coleta dos embriões e fixação em paraformaldeído $4 \%$ por 12 horas, a 4 ${ }^{\circ} \mathrm{C}$.

Dia 3. Remoção das membranas envoltórias e estocagem em etanol $70 \%$ a -20 ${ }^{\circ} \mathrm{C}$.

Dia 4. Pré-hibridização e hibridização.

- Desidratação em $1 \mathrm{ml}$ etanol $80 \%$ por 2 min.

- Desidratação em $1 \mathrm{ml}$ etanol 95\% por 2 min.

- Desidratação em $1 \mathrm{ml}$ etanol 100\% por 2 min.

- Lavagens em $1 \mathrm{ml}$ etanol $100 \%$ por 5 min.

- Incubação em $1 \mathrm{ml}$ de solução contendo etanol 50\%/xileno $50 \%$ por $5 \mathrm{~min}$.

- Incubação em $1 \mathrm{ml}$ xileno por $30 \mathrm{~min}$.

- Lavagens rápidas (5 vezes) em $1 \mathrm{ml}$ etanol 100\%. - Hidratação em $1 \mathrm{ml}$ etanol $95 \%$ por 2 min.

- Hidratação em $1 \mathrm{ml}$ etanol $80 \%$ por 2 min.

- Hidratação em $1 \mathrm{ml}$ etanol $70 \%$ por 2 min.

- Lavagens (3 vezes) em $1 \mathrm{ml}$ PBT.3 (PBS 1X contendo 0,3\% TRITON X-100) por 2 min. cada lavagem.

- Digestão dos embriões em $1 \mathrm{ml}$ de tampão proteinase K $(100 \mathrm{mM}$ TRIS-HCl $\mathrm{pH} 8,0 ; 50 \mathrm{mM}$ EDTA; $30 \mu \mathrm{g} / \mathrm{ml}$ proteinase $\mathrm{K}$ ) por 2 a $5 \mathrm{~min}$. a $37^{\circ} \mathrm{C}$.

- Lavagens (3 vezes) em $1 \mathrm{ml}$ PBT.3 por 2 min. cada lavagem.

- Incubação por 10 min. em $200 \mu l$ de solução de hibridização 50\% (50\% formamida, 4X SSC, 1X Denhardt's solution, 0,5 $\mu \mathrm{g} / \mu \mathrm{l}$ DNA de esperma de salmão desnaturado, $0,25 \mu \mathrm{g} / \mu \mathrm{l}$ tRNA de levedura e $10 \%$ dextran sulfate)/PBT.3 $50 \%$.

PRÉ-HIBRIDIZAÇÃO: 3 horas a $60^{\circ} \mathrm{C}$ em $100 \mu$ solução de hibridização (50\% formamida, 4X SSC, 1 X Denhardt's solution, $0,5 \mu \mathrm{g} / \mu \mathrm{I}$ DNA de esperma de salmão desnaturado, $0,25 \mu \mathrm{g} / \mu \mathrm{l}$ tRNA de levedura e $10 \%$ dextran sulfate).

HIBRIDIZAÇÃO: 45 horas a $60{ }^{\circ} \mathrm{C}$ em $100 \mu \mathrm{l}$ de solução de hibridização contendo a sonda digoxigenina-marcada do RNA "antisense" do gene de interesse em uma concentração final de $0,3 \mathrm{ng} / \mu \mathrm{l}$. 
Dia 5. Lavagens

- $100 \mu$ solução de hibridização por 5 min. a $60^{\circ} \mathrm{C}$.

- $100 \mu$ solução de hibridização por $2: 30$ horas a $60^{\circ} \mathrm{C}$,

- $100 \mu$ solução de hibridização por 16 horas a $60^{\circ} \mathrm{C}$.

Dia 6. Lavagens e Imunodeteç̧ão

- $80 \mu$ l solução de hibridização/ $20 \mu$ PBT.3 (80\%/20\%) por 30 min.

- $60 \mu$ l solução de hibridização/ $40 \mu$ PBT.3 $(60 \% / 40 \%)$ por $30 \mathrm{~min}$.

- $40 \mu$ l solução de hibridização/ $60 \mu \mathrm{l}$ PBT.3 (40\%/60\%) por 30 min.

- $20 \mu$ l solução de hibridização/ $80 \mu \mathrm{l}$ PBT.3 (20\%/80\%) por 30 min.

- Lavagens (2 vezes) em $500 \mu$ PBT.3 por 1 hora cada lavagem.

\section{IMUNODETECÇÃO:}

- Incubação por 1 hora em $500 \mu$ PBT.3, contendo 5\% de soro de galinha sob level agitação.

- Incubação por 2 horas em $500 \mu$ PBT. 3 plus $5 \%$ de soro de galinha, contendo $0,25 \mu l$ de anti-dig acoplado à fosfatase alcalina (diluição 1:2000).

- Lavagens rápidas (2 vezes) em $500 \mu \mathrm{l}$ PBT.3 (PBS 1X plus 0,5\% TRITON X100) e estocagem a $4^{\circ} \mathrm{C}, \mathrm{O} / \mathrm{N}$.

Dia 7. Imunodetecção

- Lavagens (5 vezes) em $500 \mu$ PBT.5 por 20 min. cada lavagem.

- Lavagens (2 vezes) em $500 \mu \mathrm{l} \mathrm{CT.3} \mathrm{(100} \mathrm{mM} \mathrm{TRIS,} 150 \mathrm{mM} \mathrm{NaCl}, 25 \mathrm{mM}$ $\mathrm{MgCl}_{2}, \mathrm{pH} 9,5,0,3 \%$ TRITON X-100) por 15 min. cada lavagem.

\section{REAÇÃO DE DESENVOLVIMENTO DA COR:}

Em $1 \mathrm{ml}$ de CT (100 mM TRIS, $150 \mathrm{mM} \mathrm{NaCl}, 25 \mathrm{mM} \mathrm{MgCl}$, pH 9,5) adicionar 4,5 $\mu \mathrm{l} \mathrm{NBT} \mathrm{e} \mathrm{3,5} \mu \mathrm{l}$ X-phosphate. Esta reação ocorre em 12 horas e deve ser realizada na ausência de luz.

\section{Apêndice 2}

\section{PROTOCOLO PARA INFILTRAÇÃO DA RESINA JB-4 EM EMBRIÕES}

FIXAÇÃO - com paraformaldeído 4\%.

\section{DESIDRATAÇÃO}

1. etanol $90 \% / 5 \mathrm{~min}$./temperatura ambiente.

2. etanol $100 \% / 5 \mathrm{~min} . /$ temperatura ambiente. 


\section{PREPARAÇÃO DA RESINA}

$100 \mathrm{ml}$ solução $A \Rightarrow 0,90 \mathrm{~g}$ de catalisador.

Pesar cuidadosamente para uma polimerização correta;

Misturar até dissolver completamente.

\section{INFILTRAÇÃO}

1. Colocar $1: 1$ solução $A(+$ catalisador):etanol sob plataforma de agitação a 4\%/60 min.;

2. Remover a solução e adicionar volume total da solução A. Agitar por $60 \mathrm{~min}$.

3. Trocar novamente, agitar por $60 \mathrm{~min}$.

4. Trocar novamente, agitar a $4{ }^{\circ} \mathrm{C} / 16$ horas;

5. Trocar a solução $4 \times 30 \mathrm{~min} . / \mathrm{cada}$;

6. Manter na solução $\mathrm{A}$ sob agitação/ $4^{\circ} \mathrm{C} / 16$ horas;

\section{EMBLOCAMENTO}

1. Adicionar $1 \mathrm{ml}$ de solução $B$ em $25 \mathrm{ml}$ de solução $A(25: 1)$;

2. Agitar bem e colocar em banho gelado enquanto mistura para evitar a polimerização prematura;

3. Colocar os embriões em moldes plásticos;

4. Colocar $700 \mu l$ da solução nos moldes contendo embriões;

5. Cobrir a cavidade com parafilm para impedir a aeração e favorecer a polimerização da resina. Deixar O/N.

\section{Apêndice 3}

\section{PROTOCOLO PARA INCORPORAÇÃO DO BrdU}

1. Preparar PBS $1 X$ PH 7,2 (20ml) contendo $50 \mu \mathrm{M}$ de BrdU (kit= $10 \mu \mathrm{M})$;

2. Adicionar em placa de petri $\left(10 \mathrm{~cm}\right.$ de diâmetro) e manter à $37^{\circ} \mathrm{C}$ por $15^{\prime} \mathrm{em}$ banho-maria sob agitação;

3. Coletar os embriões(remover resíduos de membrana que podem dificultar a incorporação do Brdu), lavar brevemente por 1' em PBS(20 ml) e transferir para a solução de PBS contendo BrdU. Manter os embriões mergulhados na solução(face voltada para baixo) por $60^{\prime}$ à $37^{\circ} \mathrm{C}$;

4. Verificar se os embriões estão vivos;

5. Retirar os embriões e lavar 2 vezes em $\mathrm{PBS}(20 \mathrm{ml})$ à $37^{\circ} \mathrm{C}$ por $15^{\prime} \mathrm{cada}$;

6. Fixar os embriões com paraformaldeído $4 \%$ por 60 ';

7. Desidratar em etanol $70 \%$ por $5^{\prime}$ ou 12 horas(hibridização). 


\section{Apêndice 4}

\section{DETECÇÃO DO BrdU EM LÂMINAS}

1. Incubar as lâminas em $30 \mathrm{ml}$ de $\mathrm{TS}$ por $30 \mathrm{~min}$. à $37^{\circ} \mathrm{C}$ contendo pronase $\mathrm{E}$ $(10 \mu \mathrm{g} / \mathrm{ml})$. Secar brevemente em papel filtro.

2. Inativar a pronase à $65^{\circ} \mathrm{C}$ por $10 \mathrm{~min}$. Incubar a lâmina em $30 \mathrm{ml}$ de $0,5 \mathrm{M}$ de tampão glicina pH 2.0 por $10 \mathrm{~min}$. à T.A. Lavar em PBT $0,1 \%$ por $10 \mathrm{~min}$. Remover o excesso de umidade com papel filtro.

3. Adicionar na lâmina $50-60 \mu \mathrm{l}$ de tampão de incubação contendo anti-BrdU (1:10), cobrir com parafilm e manter à $37^{\circ} \mathrm{C}$ por $30 \mathrm{~min}$. (39 $\mathrm{C}$ no banhomaria)

4. Lavar 2 X em $30 \mathrm{ml}$ de PBT 0,1\% por $15 \mathrm{~min}$. à T.A. Remover o excesso de umidade.

5. Adicionar na lâmina $50-60 \mu \mathrm{l}$ de PBT $0,1 \%$ contendo anti-mouse conjugado a F.A. (1:10), cobrir com parafilm e manter à $37^{\circ} \mathrm{C}$ por $30 \mathrm{~min}$. $\left(39^{\circ} \mathrm{C}\right.$ no banhomaria).

6. Lavar como descrito anteriormente.

7. Adicionar substrato NBT $(13 \mu \mathrm{l} / 3 \mathrm{ml})$ e BICP $(10 \mu \mathrm{l} / 3 \mathrm{ml})$ em TSM. Cobrir com parafilm.

8. Revelar em ambiente escuro.

\section{Apêndice 5}

\section{Extração de RNA com Trizol LS}

\section{Protocolo:}

1. Remover o tecido a ser submetido à extração.

2. Em tubo de $1 \mathrm{ml}$, acrescentar: $750 \mu \mathrm{l}$ Trizol $+250 \mu \mathrm{l} \mathrm{H}_{2} \mathrm{O}$ DEPC

3. Incubar 5 min., $15-30^{\circ} \mathrm{C}$.

4. Acrescentar $0,2 \mathrm{ml}$ de clorofórmio.

5. Agitar vigorosamente com as mãos por 15 segundos. 
6. Incubar $15-30^{\circ} \mathrm{C}$ por 2 a 15 minutos.

7. Centrifugar a $11.000 \mathrm{rpm}(12.000 \mathrm{~g})$ por $15 \mathrm{~min}$., à temperatura de $4^{\circ} \mathrm{C}$.

8. Remover a fase aquosa(superior e translúcida) e transferir para um tubo limpo. Reservar a fase orgânica para extração de DNA.

9. Adicionar $0,5 \mathrm{ml}$ de álcool isopropílico.

10. Incubar por $10 \mathrm{~min}$., à temperatura de $15-30^{\circ} \mathrm{C}$.

11. Centrifugar a $10.000 \mathrm{rpm}(12.000 \mathrm{~g})$ por $10 \mathrm{~min}$., à temperatura de $4^{\circ} \mathrm{C}$.

12. Descartar o sobrenadante.

13. Lavar com $1 \mathrm{ml}$ de etanol $75 \%$ gelado. Vortex para misturar.

14. Centrifugar a $9.000 \mathrm{rpm}(7.500 \mathrm{~g})$ por $5 \mathrm{~min}$., à temperatura de $4^{\circ} \mathrm{C}$.

15. Secar brevemente o RNA(à temperatura ambiente ou à vácuo).

16. Dissolver o "pellet" em $\mathrm{H}_{2} \mathrm{O}$ DEPC. Incubar por 10 min., à $55^{\circ} \mathrm{C}$ antes de levar ao gel.

\section{Apêndice 6}

\section{RT-PCR}

\section{A. Síntese da fita de ${ }_{c}$ DNA}

1. Misturar e centrifugar brevemente cada componente do Kit antes de utilizá-los.

2. Preparar(eppendorf $0,5 \mathrm{ml}$ )

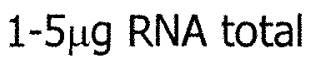

$x \mu l$

Oligo dT $(0,5 \mu \mathrm{g} / \mu \mathrm{l})$

$1 \mu l$

$\mathrm{H}_{2} \mathrm{O}$ DEPC q.s.p.

$12 \mu l$

3. Incubar as amostras à $70^{\circ} \mathrm{C}$ por $10 \mathrm{~min}$.

4. Deixar no gelo por pelo menos $1 \mathrm{~min}$.

5. Preparar a seguinte mistura de reação:

PCR buffer $10 X$

$2 \mu l$ 
$\mathrm{MgCl}_{2} 25 \mathrm{mM} \quad 2 \mu \mathrm{l}$

Mix dNTP 10mM

$1 \mu l$

DTT $0,1 \mathrm{M}$

$2 \mu l$

Total

$7 \mu \mathrm{l}$

6. Adicionar $7 \mu \mathrm{l}$ da mistura de reação em cada mistura RNA/primer. Homogeneizar delicadamente e centrifugar brevemente.

7. Incubar 5 min., $42^{\circ} \mathrm{C}$.

8. Adicionar $1 \mu \mathrm{l}(200 \mathrm{U})$ Superscript IIRT em cada tubo e incubar $42^{\circ} \mathrm{C}$ por $50 \mathrm{~min}$.

9. Interromper as reações, colocando as amostras a $70^{\circ} \mathrm{C}$ por $15 \mathrm{~min}$.

10. Retirar e deixar em gelo.

11. Coletar a reação através de breve centrifugação.

12. Adicionar $1 \mu \mathrm{l}$ de RNAse $\mathrm{H}$ em cada tubo e incubar a $37^{\circ} \mathrm{C}$ por $20 \mathrm{~min}$., antes de proceder o protocolo $B$. 